S. M. DePaoli

A. I. Rivera

B. M. Eisenhower"

*Environmental Safety and Health Division in coordination with the Oak Ridge Caseous Diffusion Plant Oak Ridge Y-12 Plant

Oak Ridge National Laboratory Paducah Gaseous Diffusion Plant Portsmouth Gaseous Diffusion Plant Operated by Martin Marietta Energy Systems, Inc., for the U.S. Department of Energy under contract DE-AC05-84OR21400 and DE-AC05-760R0001 
CONTENTS

Page

IIST OF FIGURES . . . . . . . . . . . . . . . . . . . . . . . . . v v

LIST OF TABLES. . . . . . . . . . . . . . . . . . . . . . . . . vii

ACKNOWLEDGMENTS . . . . . . . . . . . . . . . . . . . . . . . . . . ix

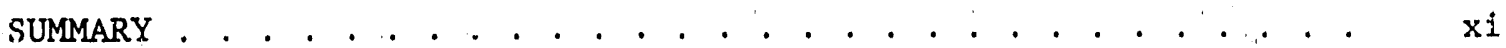

1. INTRODUCTION AND BACKGROUND . . . . . . . . . . . . . . . . . 1

2. CATEGORIZATION OF WASTE STREAMS . . . . . . . . . . . . . . . 2

3. WAST GENERATION, STORAGE TREATMENT, AND DISPOSAL . . . . . . 6

3.1 WASTE GENERATION . . . . . . . . . . . . . . . 6

3.2 WASTE STORAGE. . . . . . . . . . . . . . . . . 6

3.3 WAStE TREATMENT. . . . . . . . . . . . . . . . . . . . . 14

3.4 WASTE DISPOSAL . . . . . . . . . . . . . . . . . . . 16

4. WASTE STREAMS AT INDIVIDUAL INSTALIATIONS . . . . . . . . . . 16

4.1 PADUCAH GASEOUS DIFFUSION PLANT (PGDP) . . . . . . . . 17

4.1.1 Hazardous Waste. . . . . . . . . . . . . . . 17

4.1.2 Mixed Waste . . . . . . . . . . . . . . . . . . 17

4.2 OAK RIDGE GASEOUS DIFFUSION PLANT (ORGDP). . . . . . . . 17

4.2.1 Hazardous Waste. . . . . . . . . . . . . . . . 17

4.2.2 Mixed Waste. . . . . . . . . . . . . . . . 19

4.3 PORTSMOUTH GASEOUS DIFFUSION PLANT (PORTS) . . . . . . . 19

4.3.1 Hazardous Waste . . . . . . . . . . . . . . . . . 19

4.3.2 Mixed Waste . . . . . . . . . . . . . . . . 19

4.4 OAK RIDGE NATIONAL LABORATORY (ORNL) . . . . . . . . . . 22

4.4.1 Hazardous Waste. . . . . . . . . . . . . . . 22

4.4.2 Mixed Waste . . . . . . . . . . . . . . 22

4.5 Y-12 PLANT . . . . . . . . . . . . . . . . . . . . . 22

4.5.1 Hazardous Waste. . . . . . . . . . . . . . 22

4.5.2 Mixed Waste . . . . . . . . . . . . . . 25 
5. REFERENCES. . . . . . . . . . . . . . . . . . . . . . . . . . 25

APPENDIX A. LISTING OF HAZARDOUS AND MIXED WASTE STREAMS, BY WASTE CATEGORY, IN THE HAZWDDD DATA BASE

APPENDIX B. TOTAL WASTE GENERATION AND INVENTORIES AT ENERGY SYSTEMS INSTALLATIONS, BY WASTE CATEGORY, FOR CALENDAR YEARS 1987 AND 1988 
1 Hazardous and mixed waste generation rates for all installations, by hazardous category, during CY 1987. . . . 9

2 Hazardous and mixed waste generation rates for all installations, by hazardous category, during CY 1988, . . . 10

3 Mixed waste inventories for all installations, by hazardous category, during 1987 . . . . . . . . . . . . 12

4 Mixed waste inventories for all installations, by hazardous category, during 1988 . . . . . . . . . . . . . . 13

5 Hazardous and mixed waste generation rates, by hazardous category, for Paducah Gaseous Diffusion Plant . . . . . . . 18

6 Hazardous and mixed waste generation rates, by hazardous category, for Oak Ridge Gaseous Diffusion Plant . . . . . 20

7 Hazardous and mixed waste generation rates, by hazardous category, for Portsmouth Gaseous Diffusion Flant. . . . . . 21

8. Hazardous and mixed waste generation rates, by hazardous category, for Oak Ridge National Laboratory . . . . . . . . 23

9 Hazardous and mixed waste generation rates, by hazardous category, for Y-12 Plant. . . . . . . . . . . . . . . . . 


\section{LIST OF TABLES}

Title

Page

1 Categorization of hazardous wastes for the HAZWDDD

Program, based on EPA hazardous waste codes . . . . . . . .

2 Hazardous and mixed waste generation rates for all installations during CY 1987 . . . . . . . . . . . . . . . . 7

3 Hazardous and mixed waste generation rates for all installations during $\mathrm{CY} 1988$. . . . . . . . . . . . . . . . 8

4 End-of-year mixed waste inventories for ali installations in CY 1987 and CY 1988 . . . . . . . . . . . . . . . . . . . 11

5 Quantities of hazardous waste shipped off-site for treatment and/or disposal by installation in CY 1988 . . . . 15 


\section{ACKNOWLEDGMENTS}

The authors would like to thank the individuals, who, at each installation, helped in acquiring the data. Oak Ridge National Laboratory personnel included C. M. Kendrick, T. T. Puett, S. R. Michaud, N. S. Dailey, and R. M. Schultz; Oak Ridge Gaseous Diffusion Plant personnel included A. G. Hodgson and B. Wjotovicz; Y-12 personnel included R. R. Kimmitt and J. K. Prazniak; G. A. Timmons provided assistance frim Portsmouth; and $R$. $K$. Dierolf provided assistance from Paducah. Many thanks go to S. L. McDaniel of the Chemical Technology Division at Oak Ridge National Laboratory for typing the report. 
A data base on hazardous and mixed waste streams generated at the five U.S. Department of Energy/Oak Ridge Operations (DOE/ORO) facilities operated by Martin Marietta Energy Systems, Inc, has been developed and maintained in support of strategic planning for the Hazardous Waste Development, Demon- stration, and Disposal (HAZWDDD) Program. This data base contains informa- tion concerning all hazardous and mixed (hazardous and low-level radioactive) waste generated, stored, treated, and disposed at the five Energy Systems installations during calendar years (CYs) 1987 and 1988. To facilitate the reporting and to establish waste management needs, a waste categorization scheme has been developed based on the major hazardous component in the particular waste stream. This categorization scheme is consistent with the Environmental Protection Agency's code numbers for hazardous waste, as formulated under the Resource Conservation and Recovery Act.

The waste stream data base for CY 1987 was documented previously in the HAZWDDD Program Plan, submitted to DOE/ORO in December 1988. This report presents an update of the HAZWDDD data base for CX 1988. Where possible, comparisons to the previous calendar year data have been made.

Data on generation rates and inventories for hazardous and mixed waste for each Energy Systems installation are presented. A detailed listing of the waste streams and characterization information is presented in Appendix A. Total waste generation rates and inventories are presented, based on hazardous waste category, in Appendix B. This report functions as an overview on current applications of waste technologies at the Energy Systems installations by presenting a discussion on treatment, storage, and disposal methods presently used for hazardous and mixed waste management. 


\title{
HAZARDOUS AND MIXED WASTE GENERATION AT THE DOE/ORO INSTALLATIONS OPERATED BY MARTIN MARIETTA ENERGY SYSTEMS, INC., DURING CALENDAR YEARS 1987 AND 1988
}

\author{
S. M. DePaoli \\ A. L. Rivera \\ B. M. Eisenhower
}

\section{INTRODUCTION AND BACKGROUND}

A program plan for the management of mixed and hazardous waste at the five Martin Marietta Energy Systems, Inc. (Energy Systems) installations was submitted to the U.S. Department of Energy/Oak Ridge Operations (DOE/ORO) in December 1988. This program was known as the Hazardous Waste Development, Demonstration, and Disposal (HAZWDDD) Program and was formed to address several waste management issues, with the main objective being to ensure that all Energy systems treatment, storage, and disposal (TSD) needs for hazardous and mixed waste were identified and planned for properly. ${ }^{1}$ In an effort to meet this goal, a data base (HAZWDDD data base) was developed and maintained. This data base contained information concerning all hazardous and mixed waste generated, stored, treated, and/or disposed at the five Energy Systems instal-lations during CY 1987. Presently, the HAZWDDD Program itself is not active; however, the data base work is continuing.

This document presents an update of the HAZWDDD data base for CY 1988. Where possible, comparisons will be made to the previous calenciar year data. Summaries and figures concerning the data are presented in the body of the report, and a breakdown of the individual waste streams is presented in Appendix A. The installations' data were cbtained primarily from the annual Resource Conservation and Recovery Act (RCRA) state reports. ${ }^{2-6}$ Additional input was provided by environmental and waste management personnel at the installations and by other reports. ${ }^{7-17}$

All five installations produce purely hazardous and mixed (lowlevel radioactive and hazardous) waste. The gaseous diffusion plants and Y-12 produce mixed waste contaminated primarily with uranium 
isotopes, while the mixed waste generated at Oak Ridge National Laboratory (ORNL) is contaminated with various radioisotopes. Generation rates of both hazardous and mixed wastes are reported, and inventories of mixecl waste are discussed.

\section{CATEGORIZATION OF WASTE STREAMS}

A categorization for both hazardous and mixed waste streams, based on the major hazardous component in the particular waste stream, was developed in the previous HAZWDDD plan to facilitate the reporting of generation rates and inventories of the wastes. This categorization is based on the U.S. Environ- mental Protection Agency's (EPA's) code numbers for hazardous wastes, enume- rated by the RCRA regulations in the Code of Federal Regulations, Title 40, Part 261. ${ }^{18}$ Table 1 presents a short description of the hazardous waste categories defined for the purpose of this data base.

Categories A through D are based on the EPA's "characteristically" hazardous waste definitions and respectively assigned code numbers. Wastes in category A exhibit the characteristic of ignitability (EPA ccie D001), category B wastes exhibit the characteristlc of corrosivity (EPA code D002), wastes in category $C$ exhibit the characteristic of reactivity ( $E P A$ code $D 003$ ), and category $D$ wastes exhibit the characteristic of EP toxicity (EPA codes D004 through D017).

Categories E, F, and $G$ are based on the EPA's "Listed" hazardous wastes, specified in $40 \mathrm{CFR} 261 .{ }^{18}$ EPA 1isted wastes F001 through F005 are assigned to category E, Iisted wastes F006 through F028 are assigned to category $F$, and category $G$ wastes are all of the EPA Iisted $P$ and $U$ wastes. If a waste, hazardous or mixed, is an EPA listed hazardous waste, it remains a listed waste regardless of the treatment applied to it, whereas a characteristically hazardous waste (categories A through D) may be successfully treated to eliminate the hazardous characteristic. In order for a listed waste to be considered nonhazardous, the waste generator must go through a very involved procedure known as delisting. 
Table 1. Categorization of hazardous wastes for

the HAZWDDD Program, based on EPA hazardous waste codes

\begin{tabular}{|c|c|c|}
\hline Category & EPA $\operatorname{code}(s)$ & Description \\
\hline \multicolumn{3}{|c|}{ Characteristically hazardous wastes } \\
\hline A & D001 & $\begin{array}{l}\text { Ignitable - a waste exhibits this } \\
\text { characteristic if the waste has a flash } \\
\text { point under } 60^{\circ} \mathrm{C} \text {, or, as a solid, it is } \\
\text { capable of causing fire through frictior } \\
\text { at standard temperature and pressure } \\
\text { (see } 40 \mathrm{CFR} 261.21 \text { ). }\end{array}$ \\
\hline B & D002 & $\begin{array}{l}\text { Corrosive a waste exhibits this } \\
\text { characteristic if the pH is }<2 \text { or }>12.5 \text {, } \\
\text { or if it corrodes stee1 at a specified } \\
\text { rate (see } 40 \text { CFR 261.22). }\end{array}$ \\
\hline C & 12003 & $\begin{array}{l}\text { Reactive - a waste exhibits reactivity } \\
\text { if it is normally unstable, reacts } \\
\text { violently with water, is capable of } \\
\text { detonation, or gener- ates toxic gases } \\
\text { under certain conditions (see } 40 \text { CFR } \\
261.23 \text { ). }\end{array}$ \\
\hline D & D004-D017 & $\begin{array}{l}\text { EP-toxic - a waste exhibits toxicity if } \\
\text { the leachate contains certain } \\
\text { constituents (such as arsenic, lead, } \\
\text { mercury, and silver) at concentrations } \\
\text { equal to or higher than those given in } \\
40 \text { CFR } 261.24 \text {. }\end{array}$ \\
\hline
\end{tabular}

\section{EPA/RCRA 11sted wastes}

E F001-F005

Spent solvents - spent halogenated solvents such as trichloroethylene (TCE) and chlorinated fluorocarbons; spent nonhalogenated solvents such as acetone and methanol; also mixtures or blends containing, before use, 108 or more (by volume) of these solvents (see 40 CFR 261.31).

F F006-F028

Spent sludges - wastewater treatment sludges from electroplating operations, spent solutions from certain electroplating operations and other nonspecific sources, wastes from the production of certain chemisals (see 40 CFR 261.31 for more details). 
Table 1. (continued)

\begin{tabular}{|c|c|c|}
\hline Category & EPA code $(s)$ & Description \\
\hline \multirow[t]{2}{*}{ G } & $\begin{array}{l}\mathrm{P} 001-\mathrm{P} 123 \\
\text { and } \\
\mathrm{U} 001-\mathrm{U} 359\end{array}$ & $\begin{array}{l}\text { Discarded commercial chemicals - } \\
\text { discarded chemicals as listed in } \\
40 \mathrm{CFR} 261.33 \text {, such as cyanides, } \\
\text { benzene, chloroform, etc. }\end{array}$ \\
\hline & \multicolumn{2}{|c|}{ ISCA-regulated hazard wastes } \\
\hline \multirow[t]{2}{*}{$\mathrm{J}$} & (none) & $\begin{array}{l}\text { PCB wastes - any form of PCB-containing } \\
\text { wastes (liquid, solid, etc.). }\end{array}$ \\
\hline & \multicolumn{2}{|c|}{ Other hazardous wastes } \\
\hline $\mathrm{K}$ & (none) & $\begin{array}{l}\text { Dor polsons - hazardous wastes } \\
\text { identifled by DOT numbers but not EPA } \\
\text { codes. }\end{array}$ \\
\hline L & (none) & $\begin{array}{l}\text { Medical/infectious wastes - experimental } \\
\text { animal wastes and infectious medical } \\
\text { wastes. }\end{array}$ \\
\hline M & (none) & $\begin{array}{l}\text { Combustibles - materials that have a } \\
\text { flash point above } 60^{\circ} \mathrm{C} .\end{array}$ \\
\hline $\mathrm{U}$ & (none) & $\begin{array}{l}\text { Unknown - hazardous constituent not } \\
\text { ldentified (unknown), usually refers to } \\
\text { remedial action wastes in which the } \\
\text { wastes have not be characterized. }\end{array}$ \\
\hline $\mathrm{z}$ & (none) & $\begin{array}{l}\text { Other hazardous wastes - hazardous } \\
\text { material other than any of those } \\
\text { previously mentioned. }\end{array}$ \\
\hline
\end{tabular}


Other categories defined for the purpose of the data base are not based on EPA codes. Category $J$ wastes contain polychlorinated biphenyls (PCBS), category $\mathrm{K}$ wastes are Department of Transportation- (DOT) defined polsons not included in the EPA's RCRA regulated wastes, category $L$ wastes are infectious medical and animal wastes, category $M$ wastes are combustible wastes, category $U$ wastes contain hazardous components that have not been specifically identified, and category $Z$ wastes are all others outside of the previously mentioned categories.

A few changes have been implemented since the introduction of the HAZWDDD data base last year. Category $L$, medical and infectious waste, is not included in any of the analyses (tables and graphs) this year, mainly because the installations' records of these wastes are not kept with the records of the other categories of waste. These wastes are nat considered hazardous as defined by RCRA (except for some of ORNL's animal waste), and the majority of these wastes are autoclaved and then disposed of on-site and, thus, do not present a problem. The quantities of medical and infectious waste are very small compared with other wastes, and quantities are not expected to change significantly over the years. Appendix A, which contains a listing of all the waste streams, also includes the infectious waste streams from last year's data base.

A few changes or updates were made in the CY 1987 HAZWDDD data base information that appeared in last year's HAZWDDD Program Plan. Several CY 1987 waste streams for the Y-12 installation were modified to reflect the CY 1987 annual report data; however, overall generation rates and inventories for Y-12 were not significantly affected. All other CY 1987 installation data remained the same. Appendix A contains a listing, by waste stream, for each installation with the 1987 and 1988 generation rates and inventories. Note that several waste streams at each installation were introduced in the previous report ${ }^{1}$ have been deleted in the CY 1988 data base, and a few waste streams have been added. 
3. WASTE GENERATION, STORAGE, TREATMENT, AND DISPOSAL

\subsection{WASTE GENERATION}

Generation rates of hazardous and mixed wastes at the five installations are summarized in Table 2 for CY 1987. Table 3 contains the CY 1988 generation rates for the installations. Although it appears that, overall, the total generation of hazardous and mixed waste has increased from 1987 to 1988 , this is a broad generalization and must be reviewed more closely. Section 4 details the changes in each installation's waste generation, and the reader is referred to that section for a complete explanation of the differences in generation rates.

Figure 1 recaps the generation rates of both hazardous and $\mathrm{m}$ ixed wastes, by hazardous waste category, for CY 1987, and Fig. 2 shows the categorized generation rates of hazardous and mixed wastes for CY 1988. Comparisons between 1987 and 1988 total waste generation rates and mixed waste inventories are made in Figs. B.1 through B.16 in Appendix B.

\subsection{WASTE STORAGE}

Inventories for all installations' hazardous wastes are, generally, ambiguous because most purely hazardous wastes are treated and/or disposed of off-site by conmercial vendors. Therefore, inventories of hazardous wastes were not tracked in this update of the HAZWDDD data base. Appendir a contains the hazardous waste inventories reported for the CY 1987 data base but does not include CY 1988 inventories for these hazardous wastes. Usually, hazardous wastes are stored on-site temporarily until a sufficient quantity is accumulated and can be disposed of by a commercial vendor.

Table 4 summarizes the inventories at the end of CY 1987 and CY 1988 for all mixed wastes at the installations. Presently, there are no permitted on- or off-site disposal facilities that accept mixed waste. Therefore, all mixed wastes have an "interim" storage status. Figures 3 and 4 show the 1987 and $1988 \mathrm{mixed}$ waste inventories at each installation for each waste category. The major portion of this mixed waste inventory is Oak Ridge Gaseous Diffusion Plant's (ORGDP's) listed 
Table 2. Hazardous and mixed waste generation rates for all installations during CY 1987

\begin{tabular}{|c|c|c|c|c|c|c|}
\hline \multirow[b]{2}{*}{$\begin{array}{l}\text { Hazardous waste } \\
\text { category }\end{array}$} & \multicolumn{6}{|c|}{ Generation rate (kg/year) by installation } \\
\hline & PGDP & ORGDP & PORTS ${ }^{\circ}$ & ORNL ${ }^{d}$ & $y-12^{\circ}$ & Total \\
\hline \multicolumn{7}{|c|}{ Bazardous waste } \\
\hline $\begin{array}{l}A \text { (d.gnitable) } \\
B \text { (oorrosive) } \\
C \text { (rsactive) } \\
D \text { (EP torio) } \\
E \text { (spent solvents) } \\
F \text { (sludges) } \\
G \text { (coms. chemicals) } \\
J \text { (PCB wasto) } \\
\text { Others }\end{array}$ & $\begin{array}{r}2,455 \\
1,818 \\
0 \\
3,704 \\
6,818 \\
0 \\
183 \\
272,727 \\
1,487\end{array}$ & $\begin{array}{r}0 \\
5,760 \\
6 \\
11,040 \\
5 \\
0 \\
460 \\
7,200 \\
300\end{array}$ & $\begin{array}{r}3,440 \\
0 \\
0 \\
0 \\
3,209 \\
0 \\
1,536 \\
400 \\
1,980\end{array}$ & $\begin{array}{r}7,835 \\
6,188 \\
30 \\
173,247 \\
2,950 \\
0 \\
1,486 \\
18,7.11 \\
47,844\end{array}$ & $\begin{array}{r}55,683 \\
4,785 \\
238 \\
21,169 \\
185,585 \\
0 \\
36,009 \\
71,450 \\
1,192\end{array}$ & $\begin{array}{r}69,423 \\
18,571 \\
274 \\
209,160 \\
208,567 \\
\quad 0 \\
39,684 \\
370,488 \\
52,803\end{array}$ \\
\hline Subtotal & 289,202 & 24,771 & 10,565 & $258 ; 301$ & 386,131 & 968,970 \\
\hline \multicolumn{7}{|c|}{ Mixed waste } \\
\hline $\begin{array}{l}A \text { (ignitable) } \\
\text { B (corxosive) } \\
C \text { (reactive) } \\
D \text { (EP toxio) } \\
\text { E (spent solvents) } \\
F \text { (sludges) } \\
G \text { (comm. chemicals) } \\
J \text { (PCB waste) } \\
\text { Othars }\end{array}$ & $\begin{array}{r}136 \\
4,999 \\
0 \\
0 \\
2,727 \\
0 \\
0 \\
45,455 \\
0\end{array}$ & $\begin{array}{r}7,550 \\
38,650 \\
0 \\
700 \\
24,125 \\
0 \\
0 \\
12,700 \\
0\end{array}$ & $\begin{array}{r}0 \\
4,200 \\
0 \\
42,614 \\
4,443 \\
0 \\
0 \\
50,683 \\
1,618\end{array}$ & $\begin{array}{r}2,030 \\
669 \\
0 \\
0 \\
17,511 \\
0 \\
606 \\
1,251 \\
81,178\end{array}$ & $\begin{array}{r}2,020 \\
1701 \\
0 \\
53,193 \\
55,612 \\
1,848,780 \\
0 \\
27,625 \\
348,600\end{array}$ & $\begin{array}{r}11,736 \\
49,219 \\
0 \\
96,507 \\
104,418 \\
1,848,780 \\
606 \\
137,714 \\
431,396\end{array}$ \\
\hline Subtotal & 53,317 & 83,725 & 103,558 & 103,245 & $2,337,531$ & $2,681,376$ \\
\hline Totel & 342,518 & 108,496 & 114,123 & 361,546 & $2,723,662$ & $3,650,346$ \\
\hline
\end{tabular}

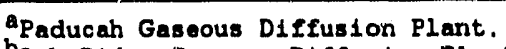

boak Ridge Gaseous Diffusion Plant.

CPortsmouth Gaseous Diffusion Plant.

doak Ridge National haboratory.

Y-12 Plant. 
Table 3. Bazardous and mixed waste generation rates for all installations during CY 1988

\begin{tabular}{|c|c|c|c|c|c|c|}
\hline \multirow{2}{*}{$\begin{array}{l}\text { Bazardous wasto } \\
\text { category }\end{array}$} & \multicolumn{6}{|c|}{ Generation rate (kg/year) by installation } \\
\hline & PGDPa & ORGDP & PORTS ${ }^{\mathrm{C}}$ & ORNL ${ }^{d}$ & $Y-12^{0}$ & Total \\
\hline \multicolumn{7}{|c|}{ Bazardous waste } \\
\hline $\begin{array}{l}A \text { (Ignitable) } \\
B \text { (oorrosive) } \\
C \text { (reactive) } \\
D \text { (EP toxio) } \\
\text { E (spent solvents) } \\
F \text { (sludges) } \\
G \text { (comp chemicals) } \\
J \text { (PCB wast } \theta \text { ) } \\
\text { Others }\end{array}$ & $\begin{array}{r}5,719 \\
119 \\
0 \\
3,80.9 \\
8,560 \\
0 \\
3 \\
392,250 \\
2\end{array}$ & $\begin{array}{r}1,783 \\
2,522 \\
1,101 \\
12,403 \\
1,797 \\
0 \\
0 \\
22,944 \\
462\end{array}$ & $\begin{array}{r}8,431 \\
249 \\
0 \\
15,861 \\
22,726 \\
0 \\
778 \\
6,745 \\
0\end{array}$ & $\begin{array}{r}13,912 \\
13,076 \\
1,679 \\
40,198 \\
4,357 \\
0 \\
810 \\
16,016 \\
39,738\end{array}$ & $\begin{array}{r}24,190 \\
4,289 \\
65 \\
96,849 \\
50,610 \\
0 \\
803 \\
557,055 \\
412\end{array}$ & $\begin{array}{r}54,045 \\
20,255 \\
2,845 \\
169,320 \\
88,050 \\
0 \\
2,394 \\
895,010 \\
40,614\end{array}$ \\
\hline Subtotal & 410,462 & 43,022 & 54,890 & 129,786 & 734,373 & $1,372,533$ \\
\hline \multicolumn{7}{|c|}{ Mirod waste } \\
\hline $\begin{array}{l}\text { A (1gnitable) } \\
B \text { (corrosivo) } \\
C \text { (reactive) } \\
D \text { (EP toxio) } \\
\text { E (spent solvents) } \\
\text { F (s ludges) } \\
G \text { (como, chemicals) } \\
\text { J (PCB wasta) } \\
\text { Others }\end{array}$ & $\begin{array}{r}226 \\
4,482 \\
0 \\
7,204 \\
5,382 \\
0 \\
0 \\
324,385 \\
0\end{array}$ & $\begin{array}{r}9,720 \\
26,485 \\
0 \\
540 \\
106,600 \\
2,400 \\
0 \\
11,742 \\
0\end{array}$ & $\begin{array}{r}3,298 \\
752 \\
0 \\
58,802 \\
25,396 \\
0 \\
47 \\
1,580,075 \\
0\end{array}$ & $\begin{array}{r}690 \\
460 \\
0 \\
273 \\
11,954 \\
0 \\
3 \\
0 \\
9,159\end{array}$ & $\begin{array}{r}2,427 \\
2,235 \\
0 \\
7,168 \\
38,652 \\
871,668 \\
0 \\
704,736 \\
348,600\end{array}$ & $\begin{array}{r}16,361 \\
34,414 \\
0 \\
73,987 \\
187,984 \\
874,068 \\
50 \\
2,620,938 \\
357,759\end{array}$ \\
\hline Subtotal & 341,678 & 257,487 & $1,668,370$ & 22.539 & $1,875,486$ & $4,165,561$ \\
\hline Totel & 752,141 & 200,509 & $1,723,260$ & 152,325 & $2,709,850$ & $5,538,094$ \\
\hline
\end{tabular}

apaducah Gaseous Diffusion Plant.

boak Ridge Gaseous Diffusion Plant.

CPortsmouth Gaseous Diffusion Plant.

dOak Ridge National Laboratory.

Y 12 . Plant. 


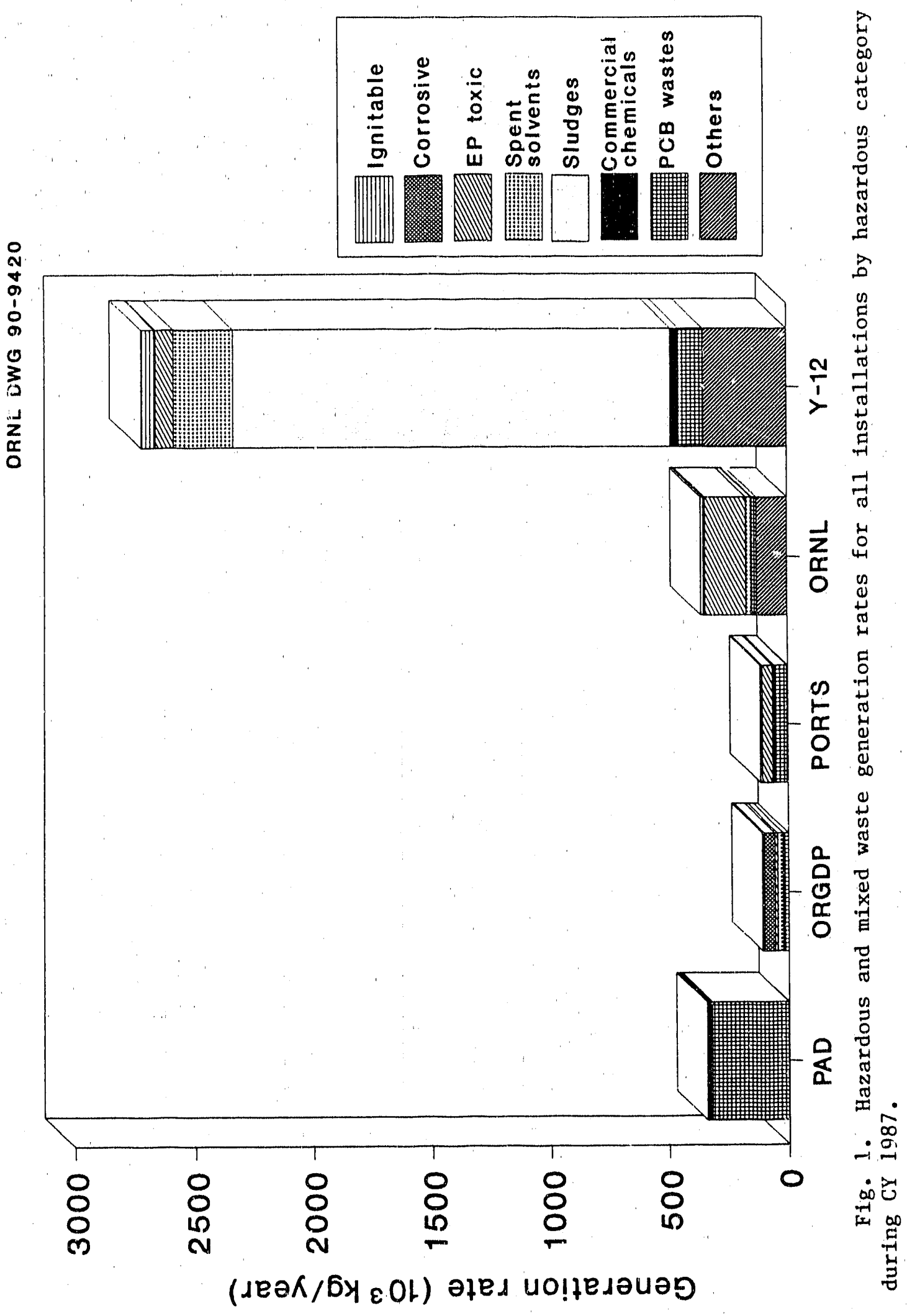




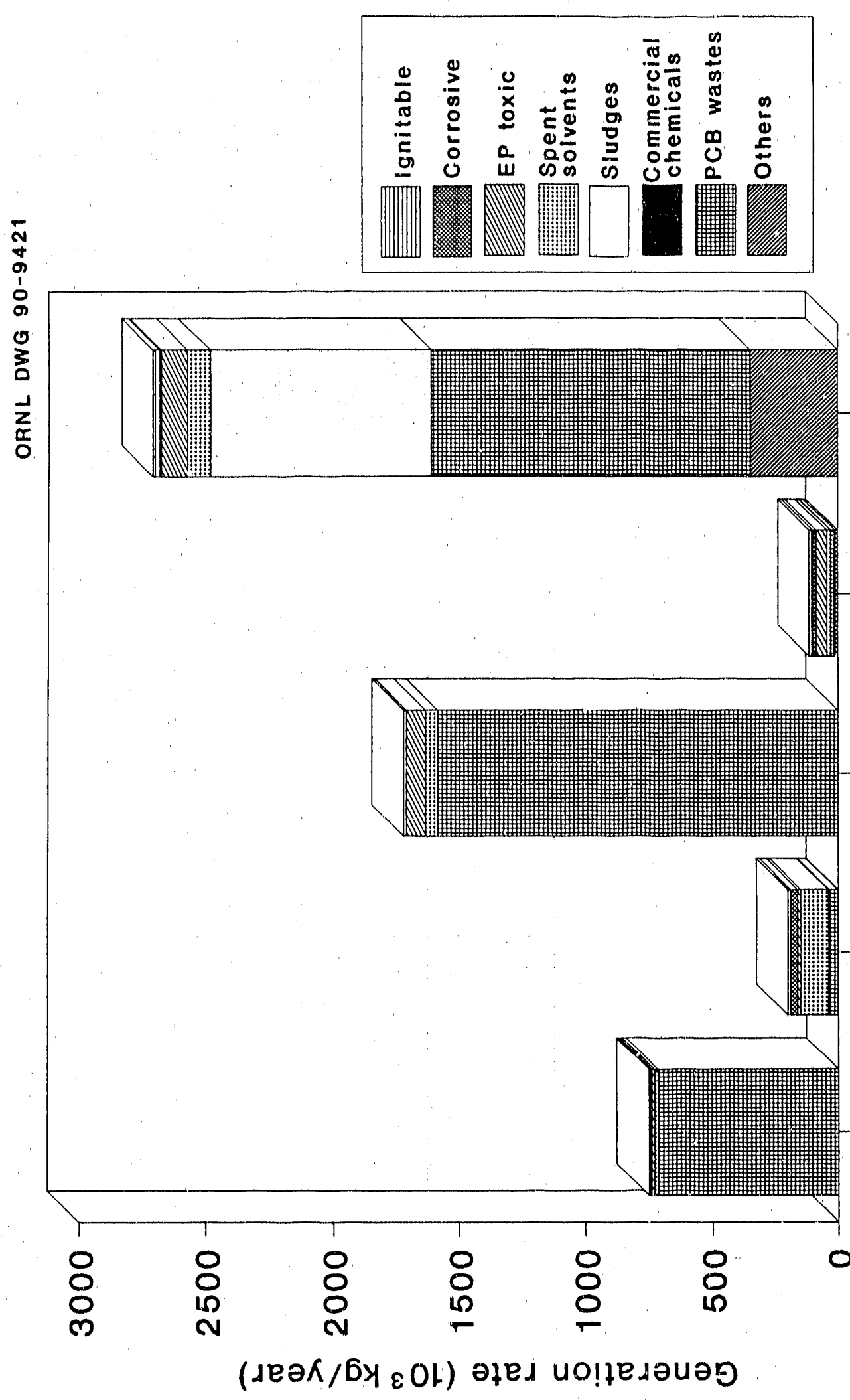

帒
0
0
0
0
0
0

ป

?

$\frac{N}{1}$

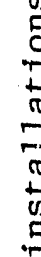

त्र

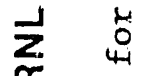

0

U

B

0
+
0
0
3
0
0

$\underset{0}{0} \stackrel{d}{0}$

0

สี

인.

苟 
Table 4. End-of-year mixed waste inventorles for all installations in 1987 and 1988

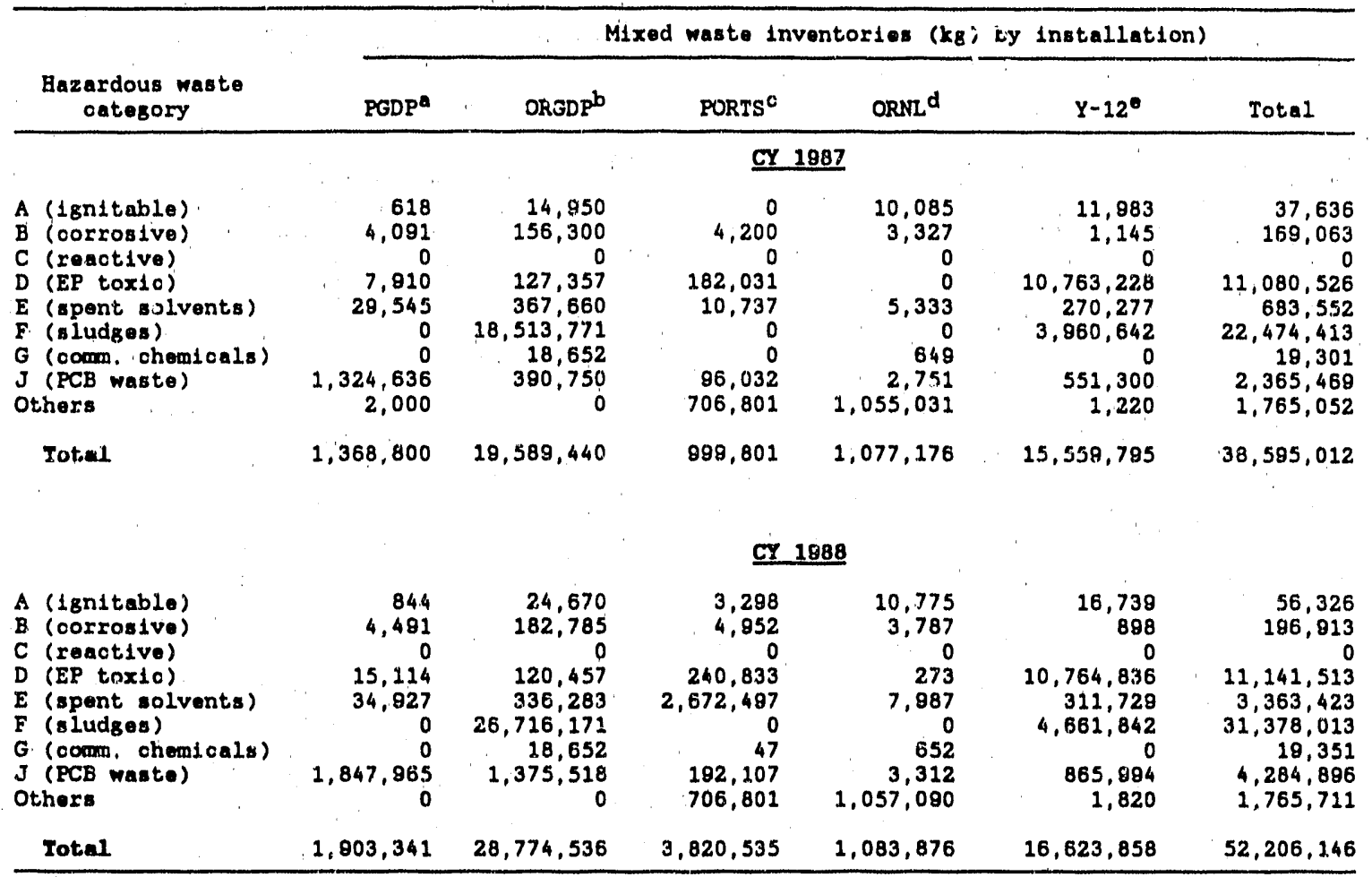

APaduoah Gaseous Diffusion Plant.

bak Ridge Gaseous Diffusion Plant.

OPortsmouth Gassous Diffusion Plant.

Oak Ridge Nationel Laboratory.

y-12 plant. 


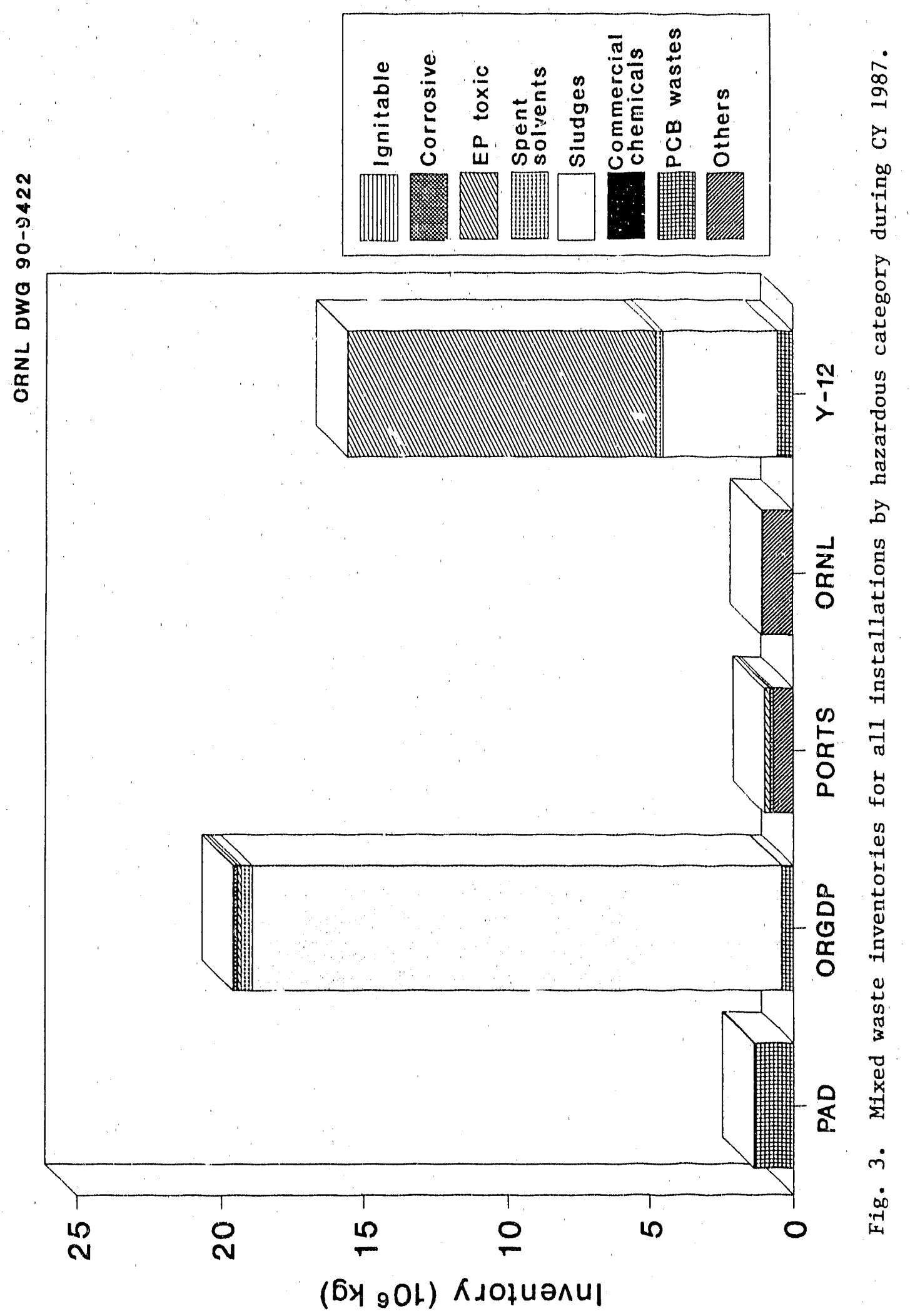




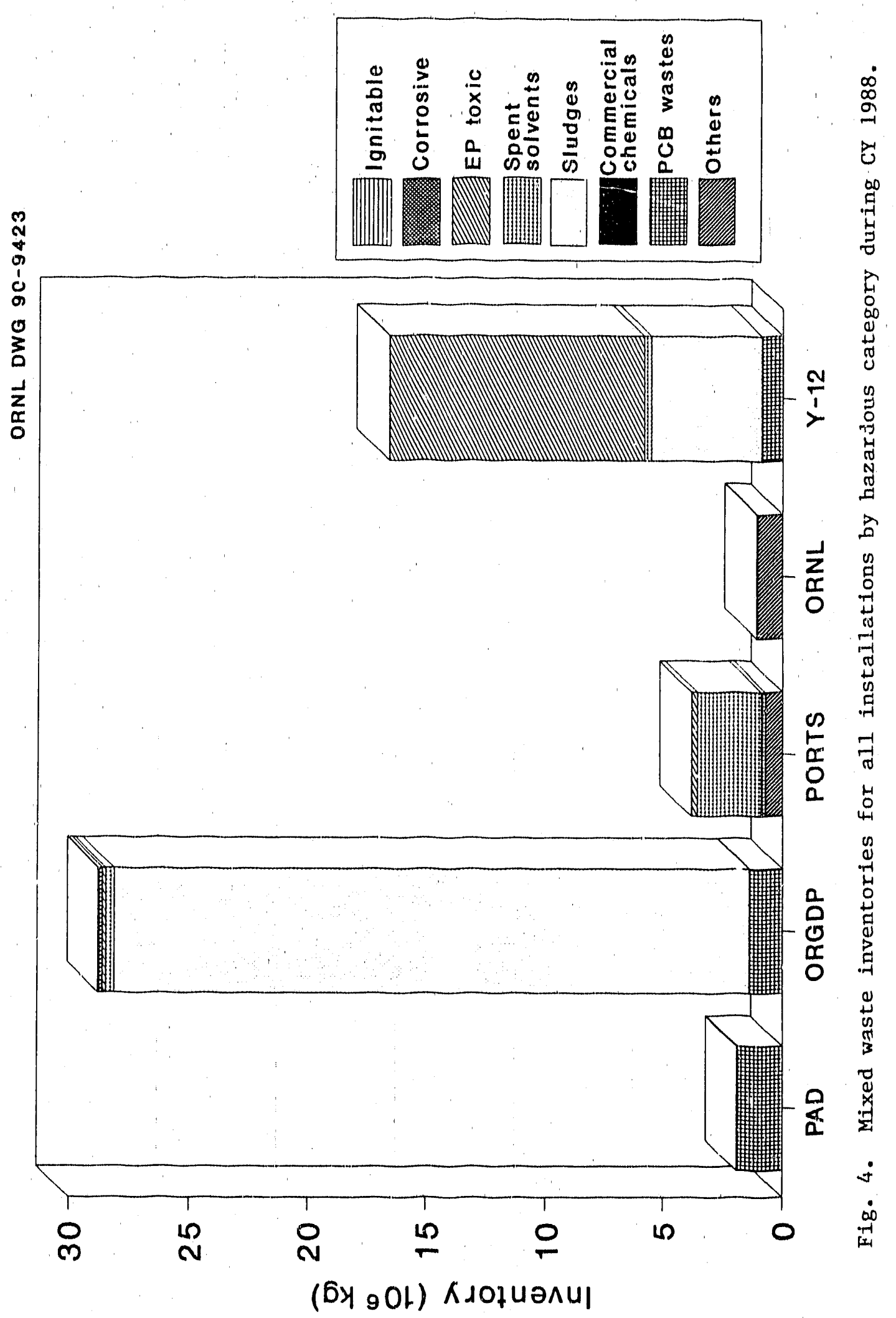


category F sludge (EPA code F006) which resulted from the closure of the $1407-B$ and $1407-C$ ponds. About 608 of this sludge is fixed in a concrete matrix; all of the sludge is contained in drums. ORGDP is currently working on delisting this material. Should the delisting procedure be successful, this waste would be reclassified as a low-level waste and disposed of appropriately. Y-12 also has a significant quantity of category $F$ sludge that is in bulk storage at the West Tank Farm. In addition, $Y-12$ has a large inventory of mixed, category $D$ (EP toxic) material in storage. The majority of this material is nonhomogeneous, mercury-contaminated rubble. Appendix $B$ contains figures showing the mixed waste inventories for all installations in each waste category.

All installations, with the exception of ORNL, have a large quantity of stored PCB-contaminated wastes. Many of these waste stream matrices are soils; about 15 wto of the waste streams are solvents. In most cases, these wastes are awaiting treatment at the Toxic Substances Control Act (TSCA) Incinerator located at ORGDP.

\subsection{WASTE TREATMENT}

Treatment capabilities for hazardous and mixed waste streams onsite at the installations are somewhat limited. As mentioned previously, most hazardous waste streams are treated and/or disposed of at off-site commercial facilities. Table 5 gives the quantities, by category, of hazardous wastes that were sent off-site for treatment and disposal in CY 1988. Most of these wastes are incinerated by commercial facilities, but in some cases, the wastes are solidified and/or landfilled.

All sites have wastewatex treatment facilities that neutralize and precipitate wastes. The Osk Ridge installations (ORNL, ORGDP, and $\mathrm{Y}-12$ ) each treat and discharge about 8 to 12 million $\mathrm{kg}$ of liquid waste per year at their water treatment facilities. Paducah and Portsmouth treat and discharge less liquid waste than this. These quantities are not included in the data base summaries because the liquids, once treated, are discharged through National Pollutant Discharge Elimination System- 
Table 5. Mass quantities ( $k g$ ) of hazardous wastes shipped off-site for treatment and/or disposal by instullations in CY 1988

\begin{tabular}{|c|c|c|c|c|c|c|}
\hline $\begin{array}{c}\text { Bazurdous waste } \\
\text { oategory }\end{array}$ & PGDPa & - ORGDPb & PORTS ${ }^{\circ}$ & ORNLd & $y-12^{\circ}$ & Total. \\
\hline$A$ & 925 & 9,641 & 153 & 9,448 & 8,552 & 28,718 \\
\hline$B$ & 0 & 2,831 & 78 & 9,458 & 6,968 & 19,336 \\
\hline c & 0 & 335 & 0 & 1,501 & 0 & 1,838 \\
\hline$D$ & 0 & $2,38:$ & 11,387 & 62,884 & 1,000 & 77,861 \\
\hline$E$ & 6,934 & 0 & 265,282 & 40,875 & 322,611 & 535,702 \\
\hline G & 0 & 1,374 & 200 & 1,054 & 5,408 & 8,036 \\
\hline $\mathrm{J}$ & 265,781 & 19,387 & 13,480 & 15,080 & 620,839 & 835,455 \\
\hline$z$ & 0 & 236 & 0 & 0 & 1,879 & 2,115 \\
\hline Totn1 & 273,640 & 36,185 & 180,568 & 141,200 & 887,266 & $1,608,080$ \\
\hline
\end{tabular}

APaducah Gasoous Diffusion Plant.

boak Ridge Gaseous Diffusion Plant.

OPortsmouth Gaseous Diefusion Plant.

doak Ridge National Laboratory.

OY-12 Plant. 
permitted points. The sludges that are produced as secondary wastes are included in the data base.

other on-site treatment facilities at the installations include reaction or detonation of reactive (category $C$, D003) waste facilities; ORGDP's stabilization faclilty for fixing waste in a concrete matrix; $Y$ 12 's sludge-drying facility; ORNL's silver-recovery facility for photographic wastes, which is not currently operating because of permitting difficulties; and the TSCA Incinerator at ORGDP, which is expected to be operating in the near future.

\subsection{WASTE DISPOSAL}

Disposal of hazardous waste is usually done off-site by commercial vendors. Incineration, which is a treatment step, is the most common means of removing the hazardous characteristics of a waste. Fixation is another common means of reducing or removing the hazardous characteristic of a waste. Landf111 of the secondary wastes (ash, in the case of incineration) is the normally practiced disposal technique in these cases.

Presently, there are no disposal facilities permitted to receive mixed waste, and, as discussed in the prevlous section, mixed wastes are stored awaiting further treatment and/or disposal. One exception is the very low-level mixed waste scintillation fluids that ORNL ships to a commercial facility for processing and incineration.

\section{WASTE STREAMS AT INDIVIDUAL INSTALLATIONS}

This section contains an analysis of the previous and current waste stream data for each individual installation. Please note that although comparisons are made between 1987 and 1988 data, the majority of these comparisons do not represent a trend in the generation of any of the particular waste categories. Trends in waste generation for these installations must be made with data for more than just 2 years. In addition, trends should be analyzed for a particular waste stream and not the broad categories of waste presented in this section. The frequency of waste stream generation must also be taken into account. 
In particular, trends for routine waste generation can be analyzed, however, nonroutine waste generation should be treated separately.

\subsection{PADUCAH GASEOUS DIFEUSION PLANT}

\subsubsection{Hazardous Waste}

Over 90 wto of Paducah's hazardous waste generation is PCBcontaminated liquids and solids. Approximately $289,000 \mathrm{~kg}$ of purely hazardous waste were generated during 1987 and $410,000 \mathrm{~kg}$ were generated during 1988. The amount of PCB-contaminated wastes (hazardous only) increased by about $120,000 \mathrm{~kg}$ from 1987 to 1988 . This additional generation of PCB-contaminated waste accounts for the difference in the total waste generation from 1987 and 1988. Figure 5 shows a category breakdown of the waste generation at PGDP for 1987 and 1988 .

\subsubsection{Mixed Haste}

PGDP's generation of mixed waste has increased from a 1987 rate of $\sim 8,000 \mathrm{~kg}$ to $-17,000 \mathrm{~kg}$ in 1988 . This increase is seen mainly in the generation of category D (EP toxic) wastes. The generation of spent solvent mixed wastes also increased from 1987 to 1988. In addition, the PCB-contaminated mixed waste generation for 1988 was $324,000 \mathrm{~kg}$, bringing the 1988 total mixed waste generation to $341,000 \mathrm{~kg}$. PCBcontaminated waste generation for 1987 was reported only for sewage sludge (no change from 1987 to 1988), not for other mixed solid and liquid PCB-contaminated wastes, so a direct comparison between 1987 and 1988 generation rates cannot be made. Figure 5 shows a breakdown of the generation rates for mixed waste as well as hazardous waste for PGDP.

\subsection{OAK RIDGE GASEOUS DIFFUSION PLANT}

\subsubsection{Hazardous Waste}

The hazardous waste generation rate for ORGDP in CY 1987 was $-25,000 \mathrm{~kg}$, and the generation rate in CY 1988 was $-43,000 \mathrm{~kg}$. The additional $18,000 \mathrm{~kg}$ of hazardous waste generated in CY 1988 were PJBcontaminated liquids and spent solvents, of which the majority was shipped in from other sites for disposal at the TSCA incinerator. 


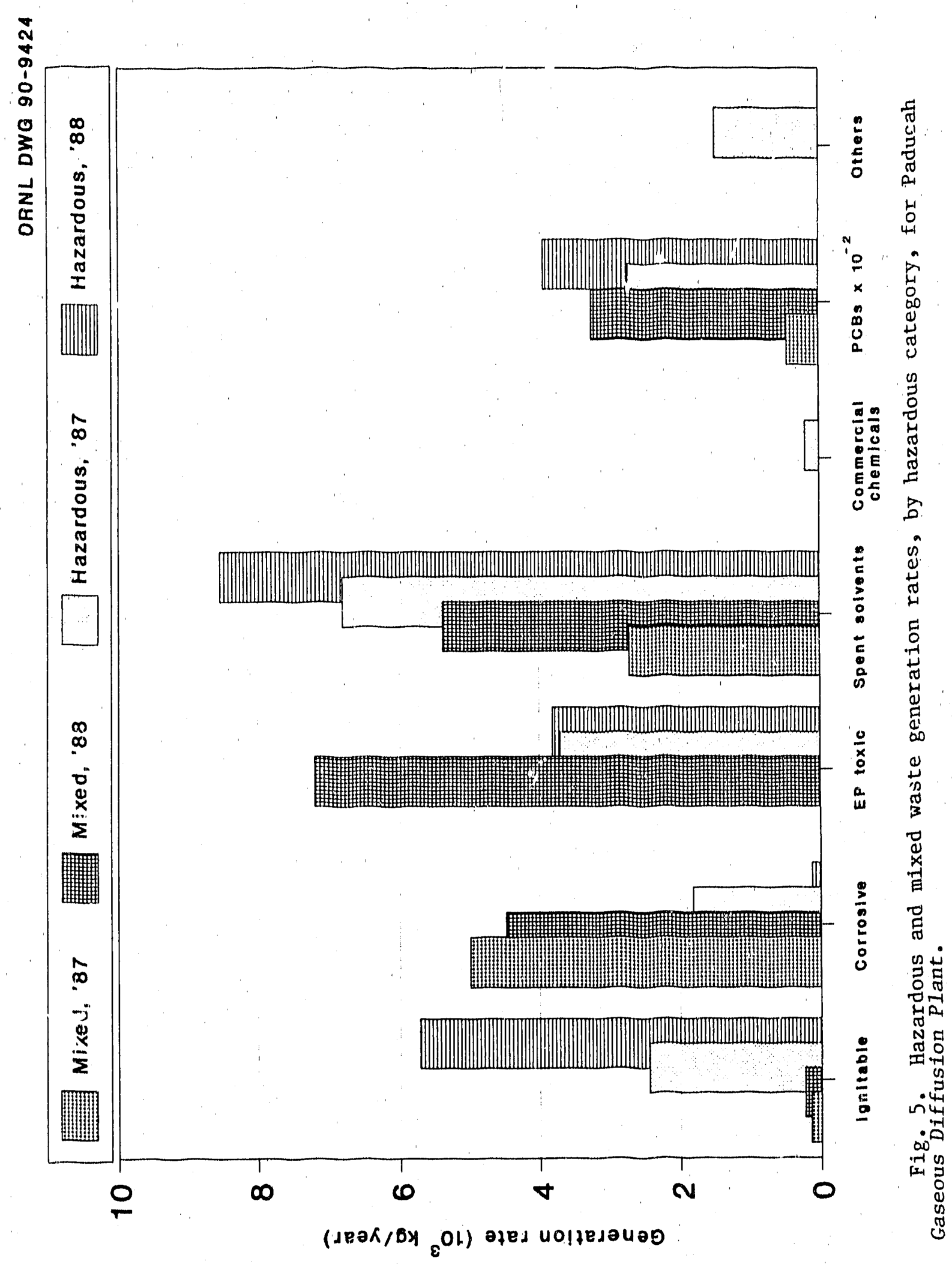


Figure 6 shows ORGDF's generation rates of the various hazardous waste categories for 1987 and 1988 .

\section{2 .2 Mixed Waste}

Mixed waste generation at ORGDP during CX 1987 was $-84,000 \mathrm{~kg}$, and the generation rate during CY 1988 was $-157,000 \mathrm{~kg}$. The differer. $\theta$, and more, is the TSCA Incinerator ash that was generated in trial burris, $-87,000 \mathrm{~kg}$ more than was generated in the 1987 trial burns. This mixed waste is classified as a spent solvent, category $E$, 1isted waste. Figure 6 shows a summary of ORGDP's mixed waste generation rates in 1987 and 1988 .

\subsection{PORTSMOUTH GASEOUS DIFEUSION PLANT}

\subsubsection{Hezardous Waste}

At PORTS, total hazardous waste generation during CY 1987 was $-11,000 \mathrm{~kg}$, compared with a generation of nearly $55,000 \mathrm{~kg}$ for 1988 . Approximately one-half of the additional $44,000 \mathrm{~kg}$ of hazardous waste generated in 1988 was solvent-contaminated liquids. In addition 15,000 $\mathrm{kg}$ of purely hazardous EP toxic wastes were generated in 1988, of which the majority was a chromic cleaning solution spill waste. Figure 7 shows the generation rates of the various categories of waste for 1987 and 1988 for PORTS.

\subsubsection{Mixed Waste}

During CY 1998, mixed waste generation at the Portsmouth installation was -1.6 million $\mathrm{kg}$. Ninety-four percent, or 1.5 million $\mathrm{kg}$, of this waste was soll contaminated with PCBs. This waste was transported to ORGDP for storage. Two other contaminated-soil streams, one containing spent solvents and the other contaminated with EP toxic constituents, account for the rest of the increased generation during CY 1988. Again, Fig. 7 shows a breakdown of the generation rates jy hazardous waste category for PORTS. 


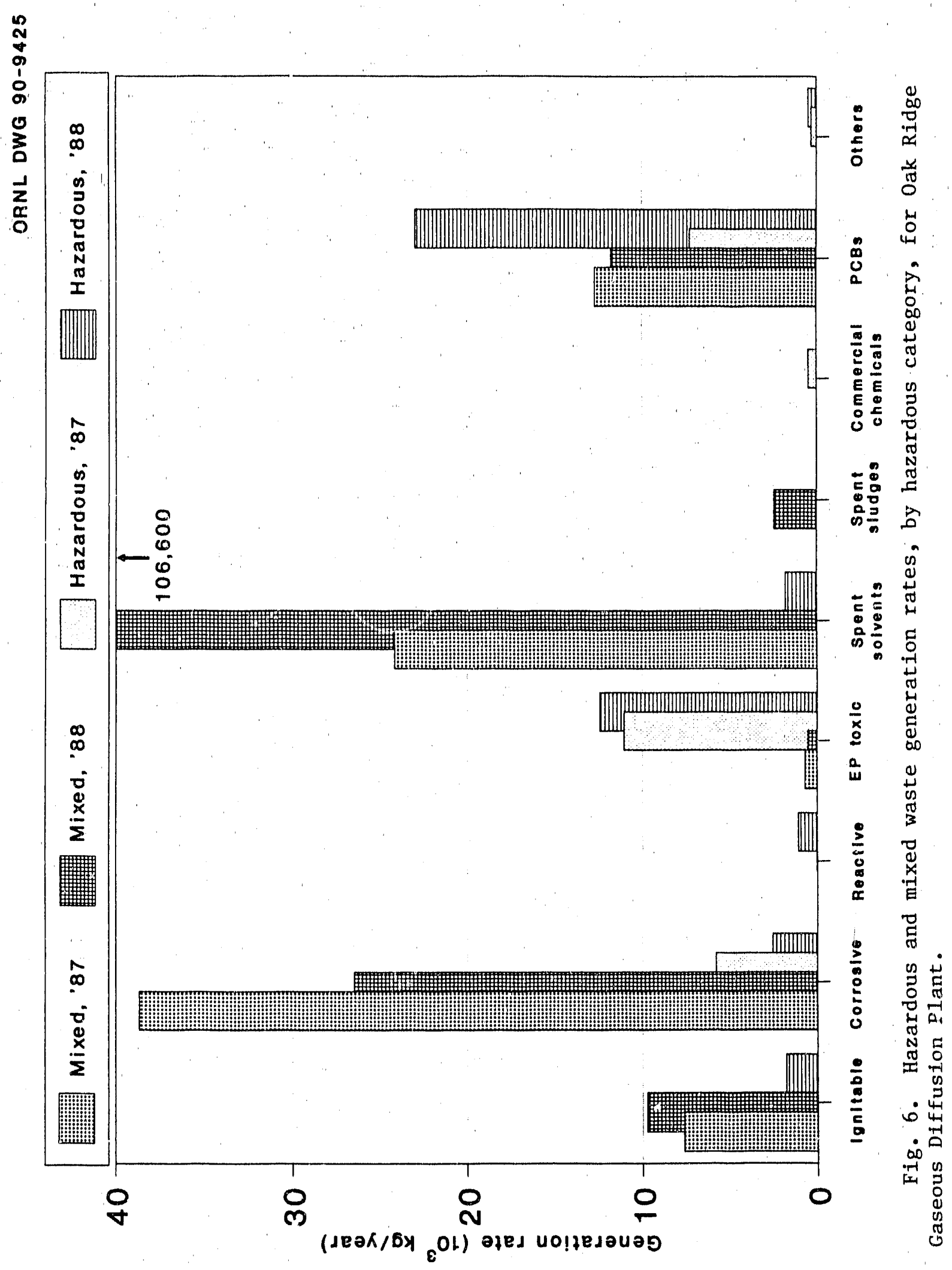




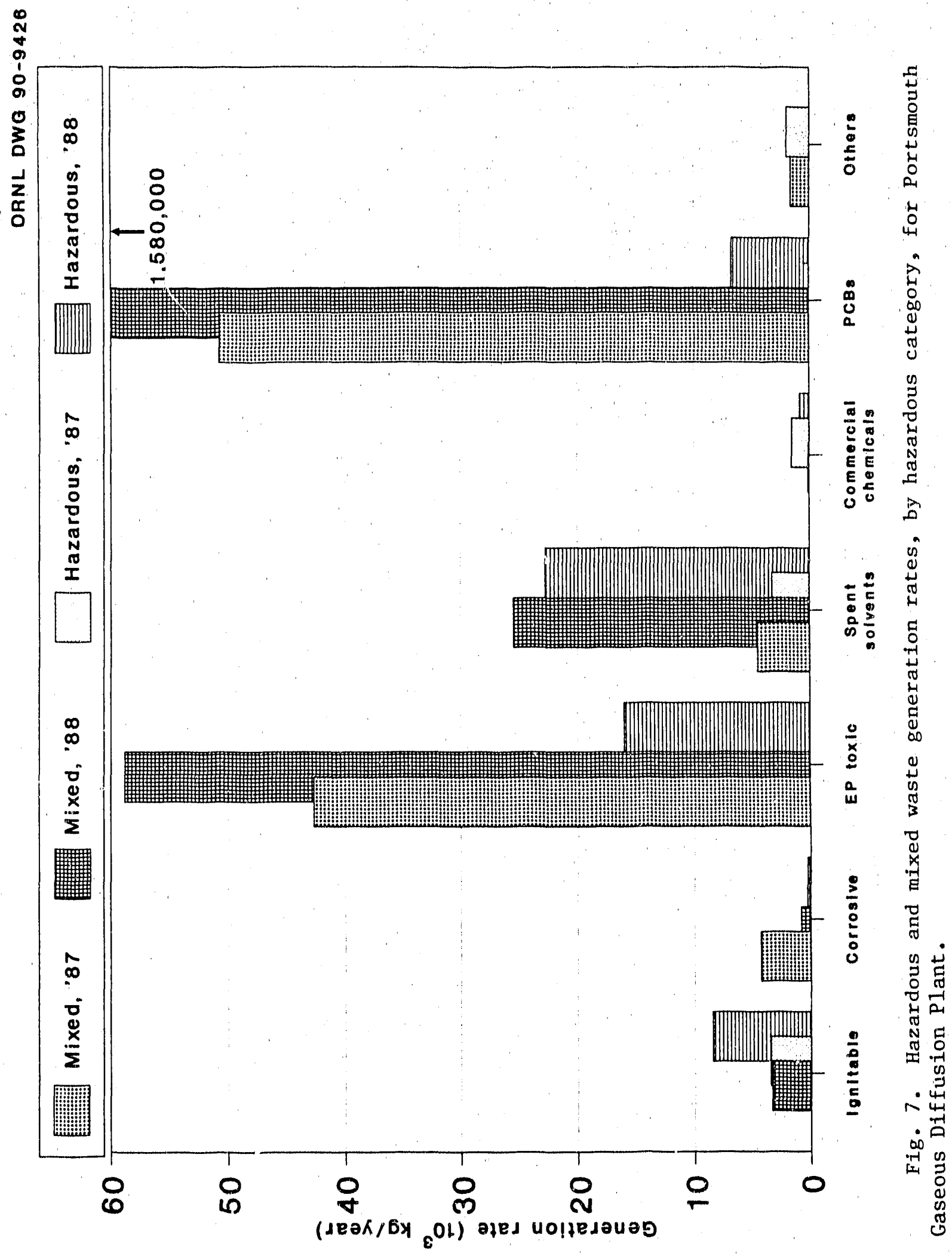




\subsection{OAK RIDGE NATIONAL LABORATORY}

\subsubsection{Hazardous Waste}

Overall, the generation of hazardous waste at ORNL has decreased from $258,000 \mathrm{~kg}$ in 1987 to $130,000 \mathrm{~kg}$ in 1988 . The decrease is seen in category D, EP toxic, waste generation. In $1987,-134,000 \mathrm{~kg}$ of EP toxic-contaminated soil was generated during remediation activities. Figure 8 shows a category breakdown of the generation of hazardous waste at ORNL for CYs 1987 and 1988.

\subsubsection{Mixed Waste}

From 1987 to 1988 , there was a reduction in total. mixed waste generation at ORNL. The 1987 generation rate was $-103,000 \mathrm{~kg}$, and the 1988 generation rate was $22,500 \mathrm{~kg}$. Again, the majority of this reduction was due to one waste stream; $71,000 \mathrm{~kg}$ of construction debris was generated in 1987. In addition to the absence of this waste stream in 1988, the spent solvent, category $\mathrm{E}$, wastes were reduced from 1987 to 1988. Figure 8 shows the generation of mixed and hazardous wastes, by hazardous category, from 1987 to 1988. Because of the inability to judge trends of waste generation based on 2 years of data, no more comparisons will be made at this time.

\subsection{Y-12 PLANT}

\subsubsection{Hazardous Waste}

The known hazardous waste generation at Y-12 during CY 1987 totalled $-386,000 \mathrm{~kg}$. During CY $1988, Y-12$ generated $-734,000 \mathrm{~kg}$ of hazardous waste. One waste stream accounted for the major difference in generation rates. In $1988,410,000 \mathrm{~kg}$ of PCB-contaminated transformers and capacitors (categoxy $J$ ) were taken out of service and disposed of in CY 1988; while in 1987 a significantly smaller quantity was removed from service. In addition, the amount of liquid PCB-contaminated wastes generated in 1988 was quantified, whereas in 1987 that quantity was not specified. However, assuming that figure did not change significantly, an overall reduction in hazardous waste generation at $\mathrm{Y}-12$ can be noted. Figure 9 shows the breakdown, by category, of waste genaration at Y-12 for 1987 and 1988. As seen in the figure, some waste categories' 


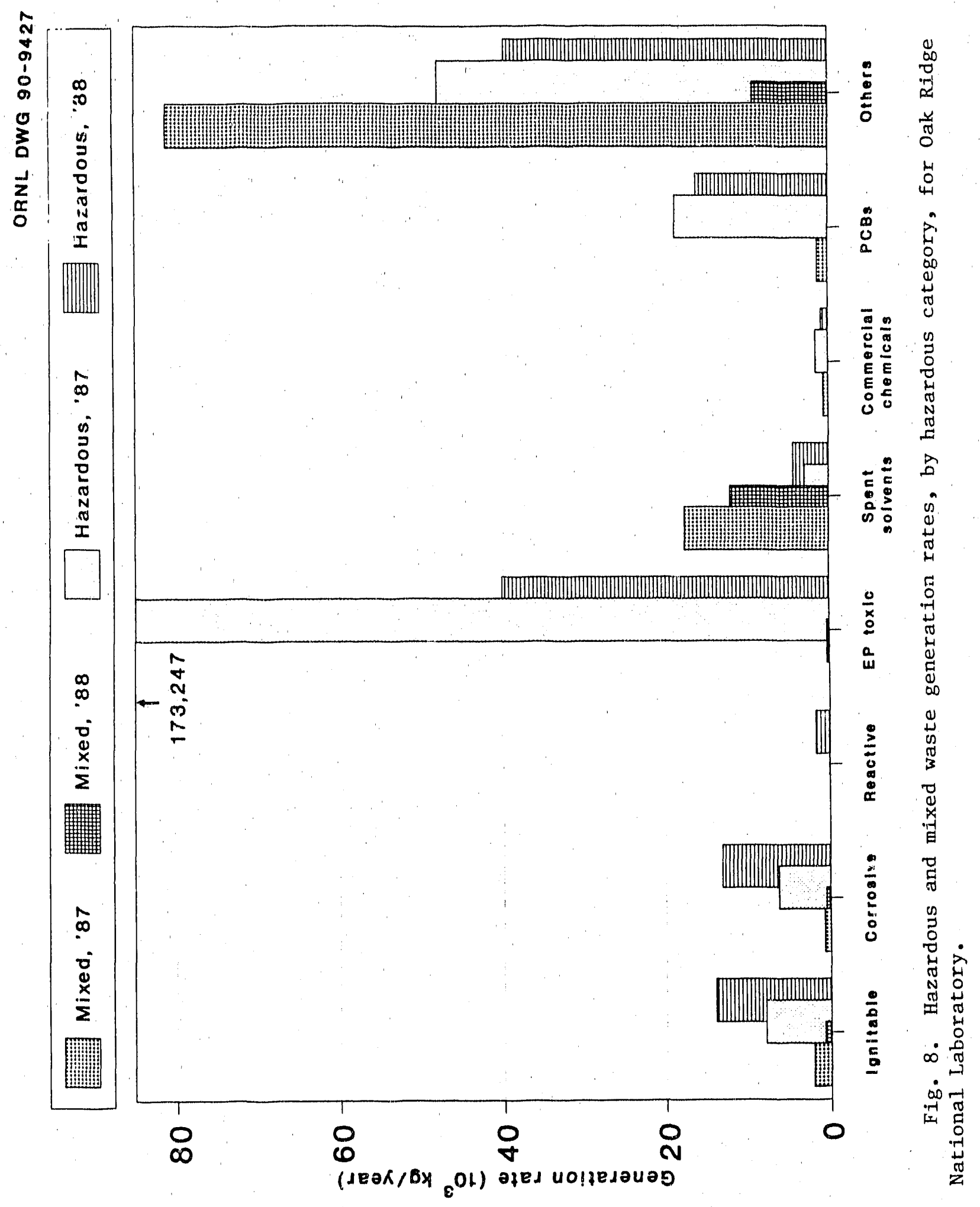




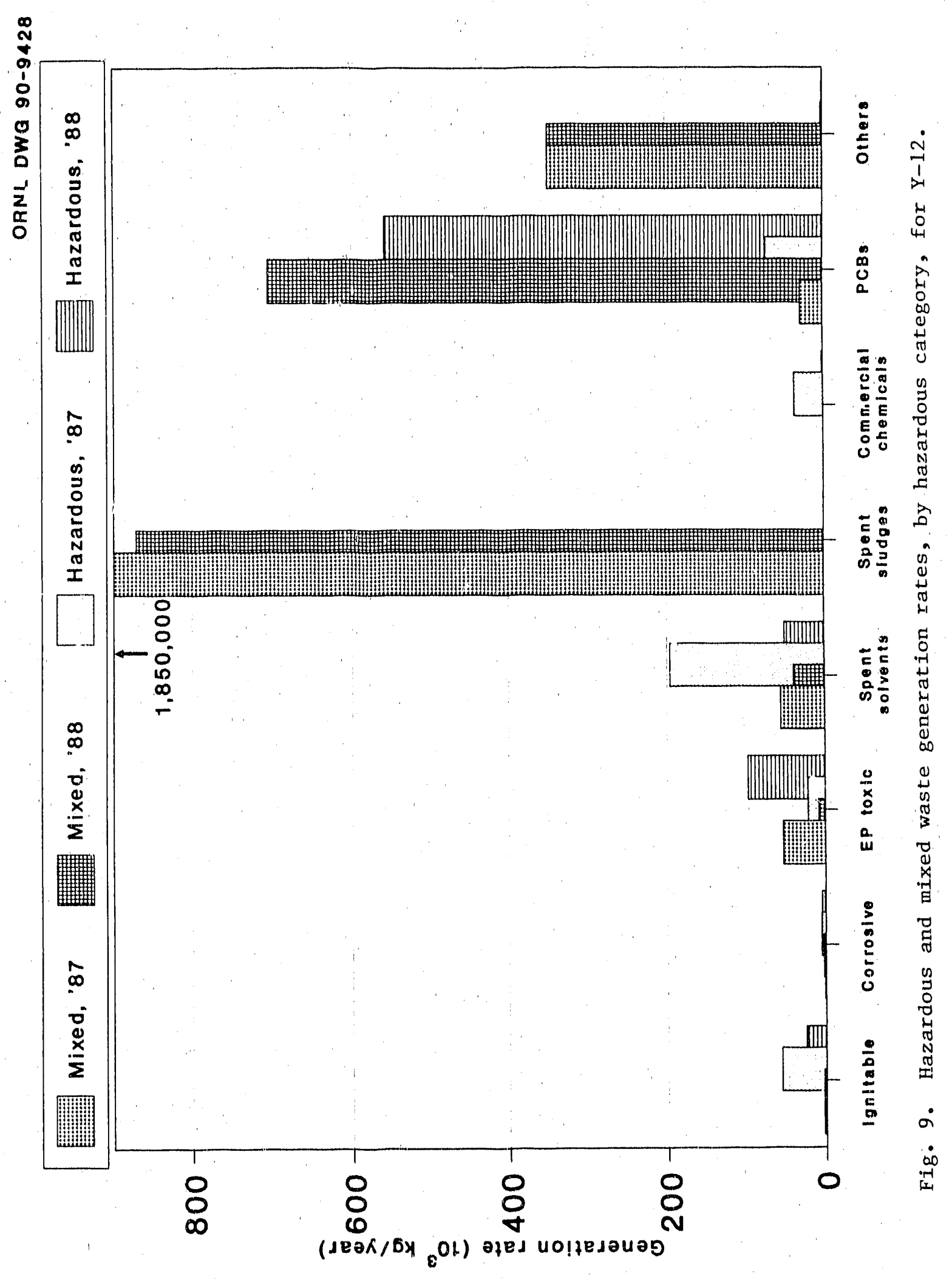


generation rates have increased and some have decreased, but as mentioned previously, there was an overall waste reduction.

\section{5 .2 Mixed waste}

The mixed waste generation at $Y-12$ has decreased in every category with the exception of PCB-contaminated wastes. The total 1987 generation rate of mixed waste at $Y-12$ was $-2.3 \mathrm{million} \mathrm{kg}$, and the mixed waste generation in 1988 was -2.0 million $\mathrm{kg}$. The largest reduction in mixed waste generation was the quantity of sludge produced in the West End Treatment Facility, which dropped by -1 million $\mathrm{kg}$ per year. This reduction is the result of an operational change thet altered $60 \%$ of the produced sludge from a mixed waste to an LLW. The increase in generation of PCB-containinated mixed waste for 1988 was largely due to the excavation of $-700,000 \mathrm{~kg}$ of the $0 \mathrm{il}$ Landfarm soils. Figure 9 shows the generation of mixed wastes for 1987 and 1988 by hazardous waste category.

\section{REFERENCES}

1. C. P. McGinnis, B. M. Elsenhower, M. E. Reeves, S. M. DePaoli, L. H. Stinton, and E. H. Harrington, Hazardous Waste Development, Demonstration, and Disposal (HAZWDDD) Program Plan, ES/ESH-5/V1, February 1989.

2. M. C. Snith, 1988 Hazardous Waste Annual Report for the Paducah Gaseous Diffusion Plant, Paducah, KY, February 1989.

3. M. Travaglini, 1988 Hazardous Waste Annual Report for the Portsmouth Gaseous Diffusion Plant, Portsmouth, OH, May 1989.

4. A. G. Hodgson, 1988 Annual Report of Hezardous Waste Activities for the Oak Ridge Gaseous Diffusion Plant, Oak Ridge, TN, March 1989.

5. N. Dailey, 1988 Hazardous Waste Notification Summary Report for Oak Ridge National Laboratory, Oak Ridge, TN, April 1989.

6. M. S. Burris, 1988 Hazardous Waste Annual Report for the $\mathrm{Y}-12$ Plant, Oak Ridge, TN, March 1989.

7. R. Keuhn, CY 1988 Polychlorinated Biphenyls (PCB) Report for the Paducah Gaseous Diffusion Plant, Paciucah, KY, June 1989.

8. G. A. Goslow and W. E. Wiehle, Polychlorinated Biphenyls (PCB): Use. Storage and Disposal at the Portsmouth Gaseous Diffusion Plant for Calendar Year 1988, Portsmouth, OH, June 1989. 
9. D. A. Coleman, 1988 Annual PCB Inventory at the Oak Ridge Gaseous Diffusion Plant, Oak Ridge, TN, June 1989.

10. N. S. Dailey, T. T. Puett, and A. R. Witt, PCB Annual Report for Dak Ridge National Laboratory - 1988, ORNL/TM-11247, June 1989 .

11. Y-12 Plant Polychlorinated Bipheny 1 (PCB) Annual Inventory Report, Health, Safety, Environment, and Accountability Division, Y/TS290/R2, June 1989.

12. R. J. Keeling, Radioactive Waste Management Plan for the Paducah Gaseous Diffusion Plant FY 1989, KY/B-265, January 1989.

13. N. S. Dailey, C. M. Kendrick, S. R. Michaud, T. T. Puett, Oak Ridge National Laboratory, personel communication, to S. M. DePaoli, ORNL, 1989.

14. R. R. Kimmitt and J. Prazniak, Y-12 Plant, personal communication, to

S. M. DePaoli, ORNL, 1989.

15. G. A. Timmons, Portsmouth Gaseous Diffusion Plant, personal communication, to S. M. DePaol1, ORNL, 1989.

16. A. G. Hodgson and B. Wojtowlcz, Oak Ridge Gaseous Diffusion Plant, personal communication, to S. M. DePaoli, ORNL, 1989.

17. R. K. Dierolf, "Paducah Gaseous Diffusion Plant Waste Management Privatization Activities," presented at the DOE Model Conference, Oak Ridge, TN, October 1989.

18. U.S. Environmental Protection Agency, "Protection of Environment," Code of Federal Regulations, 40 CFR Pt. 261, July 1, 1987. 
APPENDIX A

Listing of Hazardous and Mixed Waste Streams, by Hazardous Waste Category, in the HAZWDDD Data Base 
KEY FOR TABLES A. I I'HROUGH A,S

1. Hazardous Waste Catagory:

2. Waste ID No.:

3. Waste Type:

4. Physioal form:

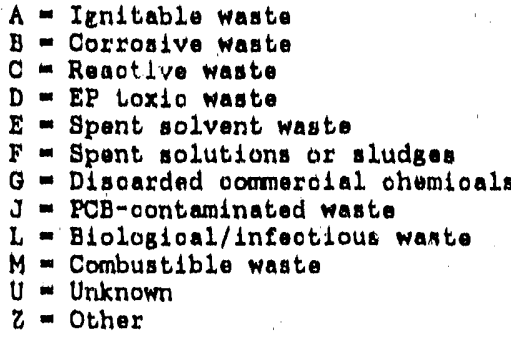

$A=$ Ienitablo wasto

- Corrosive waste

C- Reaot Ive waste

D - EP Loxto wasto

- Spent solvent wast

F - Spent solutions or sludges

G - Discardad oomercial ohomioal

I - PCB-oontaminated wasto

$L=$ Blologloal/infeotlous wante

$M=$ Combustible waste

U = Unuknown

$z$ - Other

Stream ID number in the data base

$H$ - Hazardous wasto

$M-$ Mixed waste

$B=$ Both hazarclous and mixed wastos are inoluded in the waste stroam.

5. RCRA Annual Report Stream No.1 Waste struam number of the atream(s) in the reapootivo Installation's annual report. 


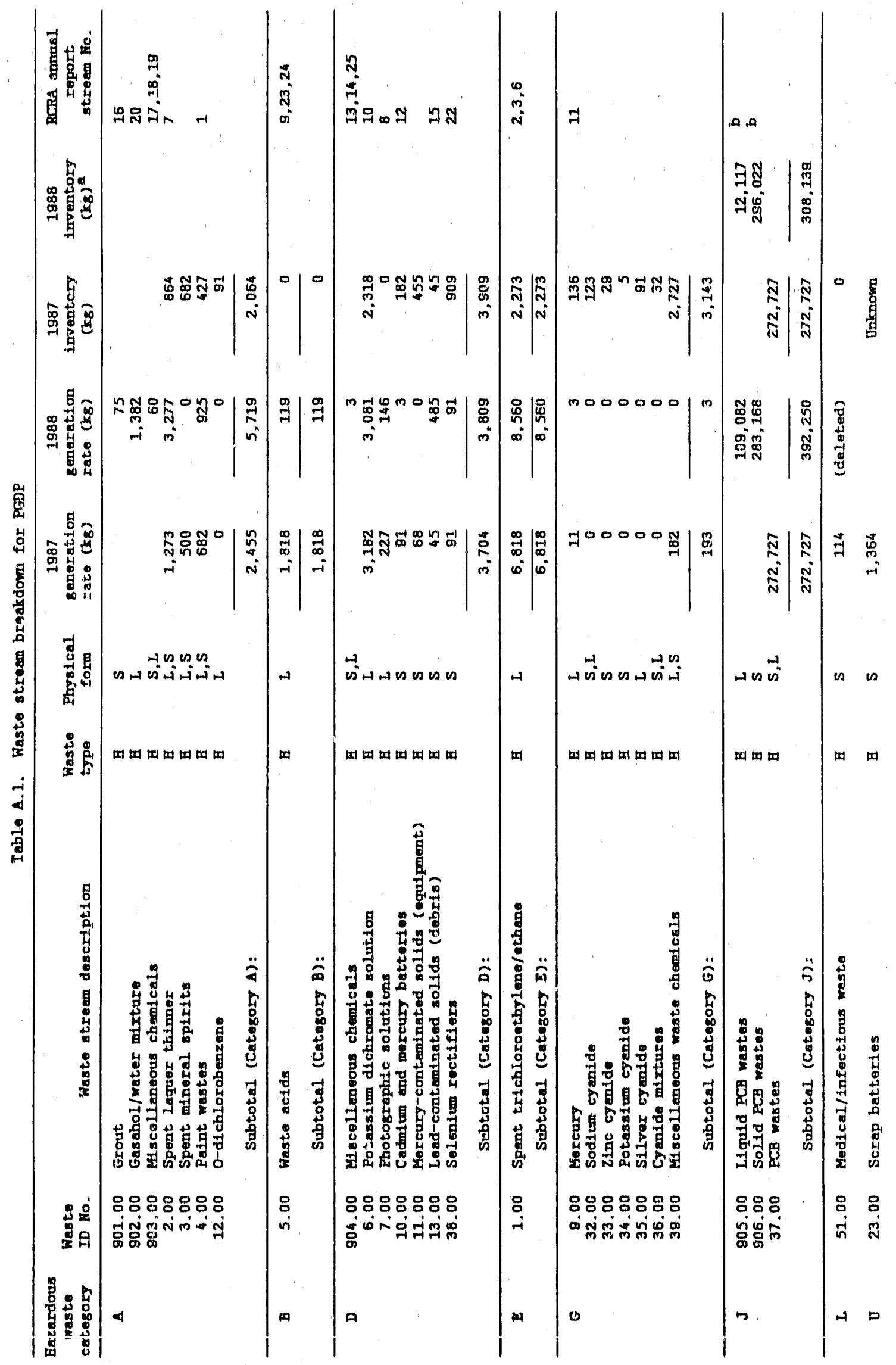




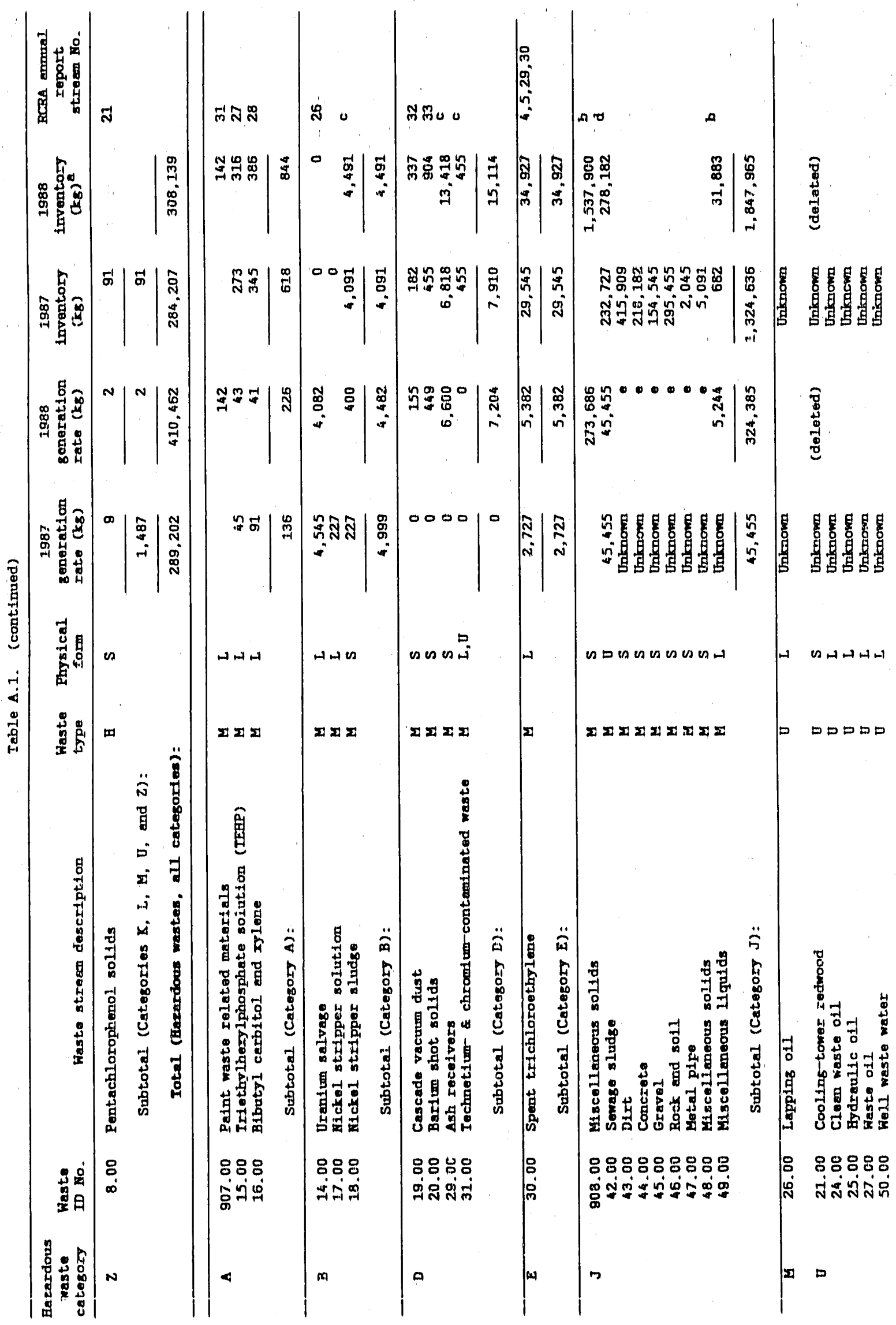




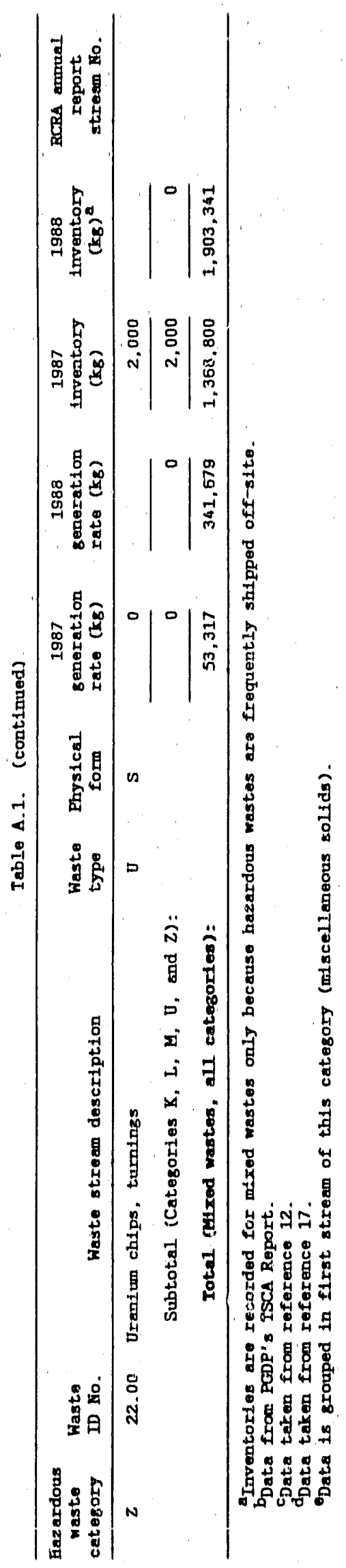




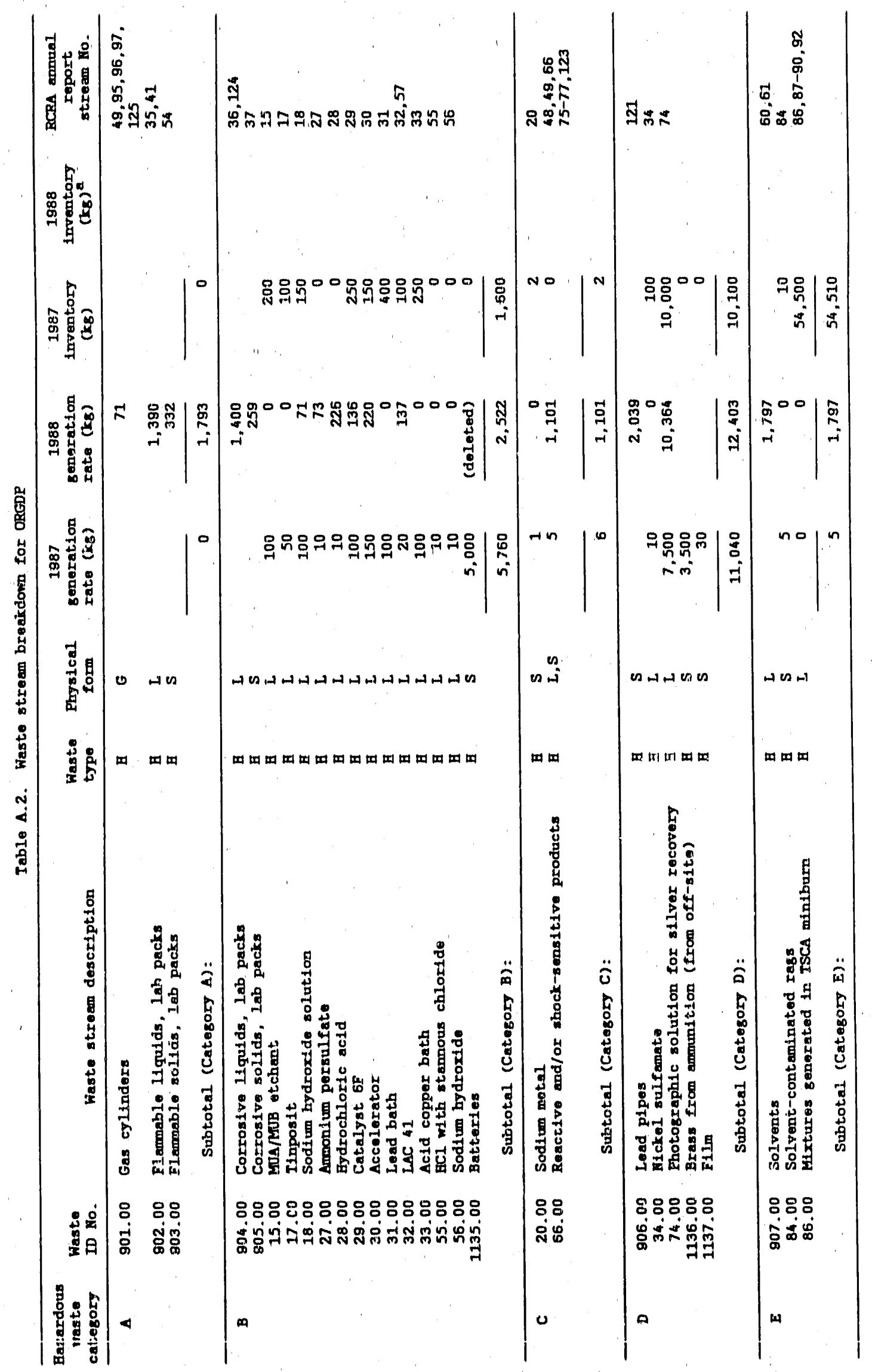




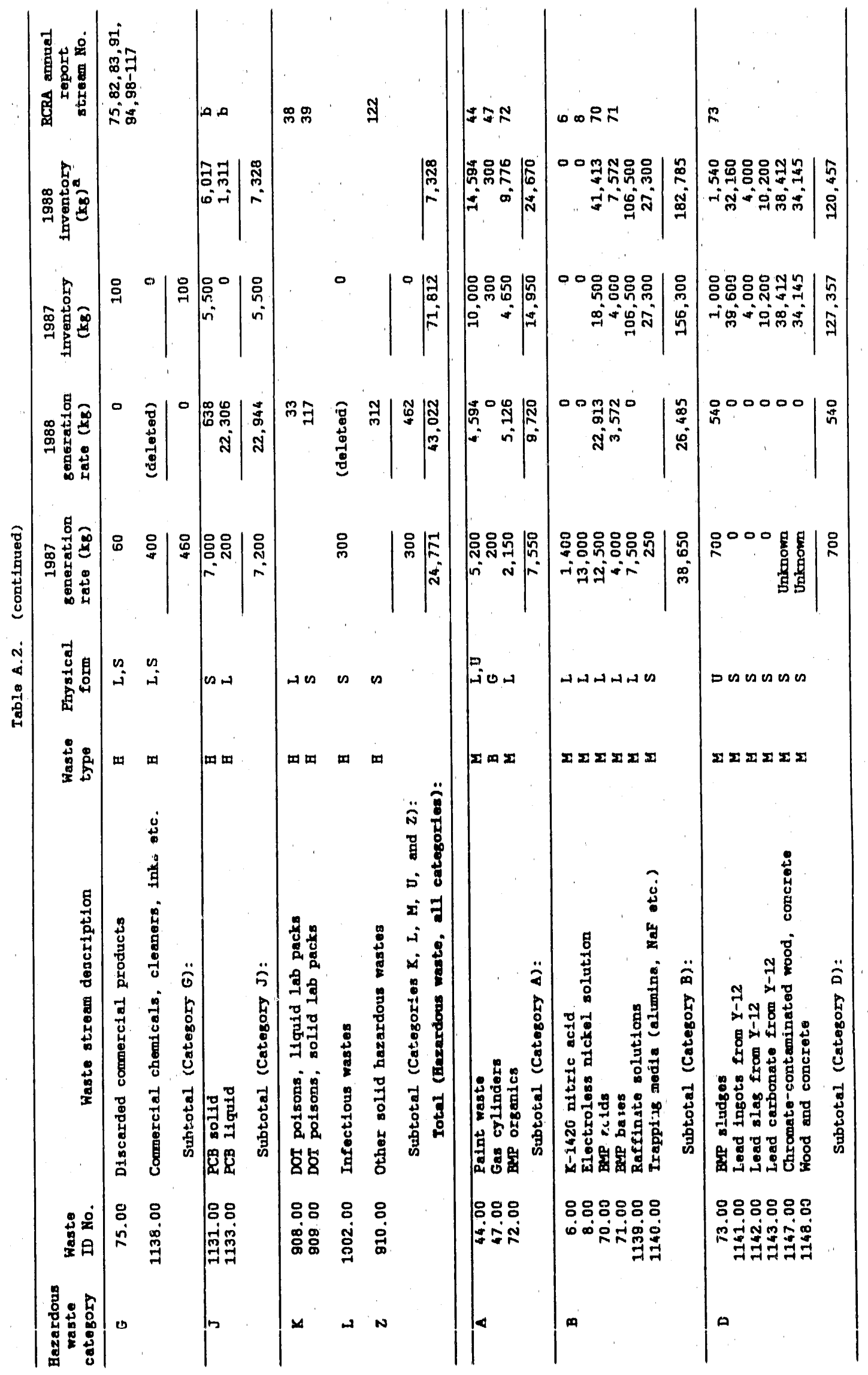




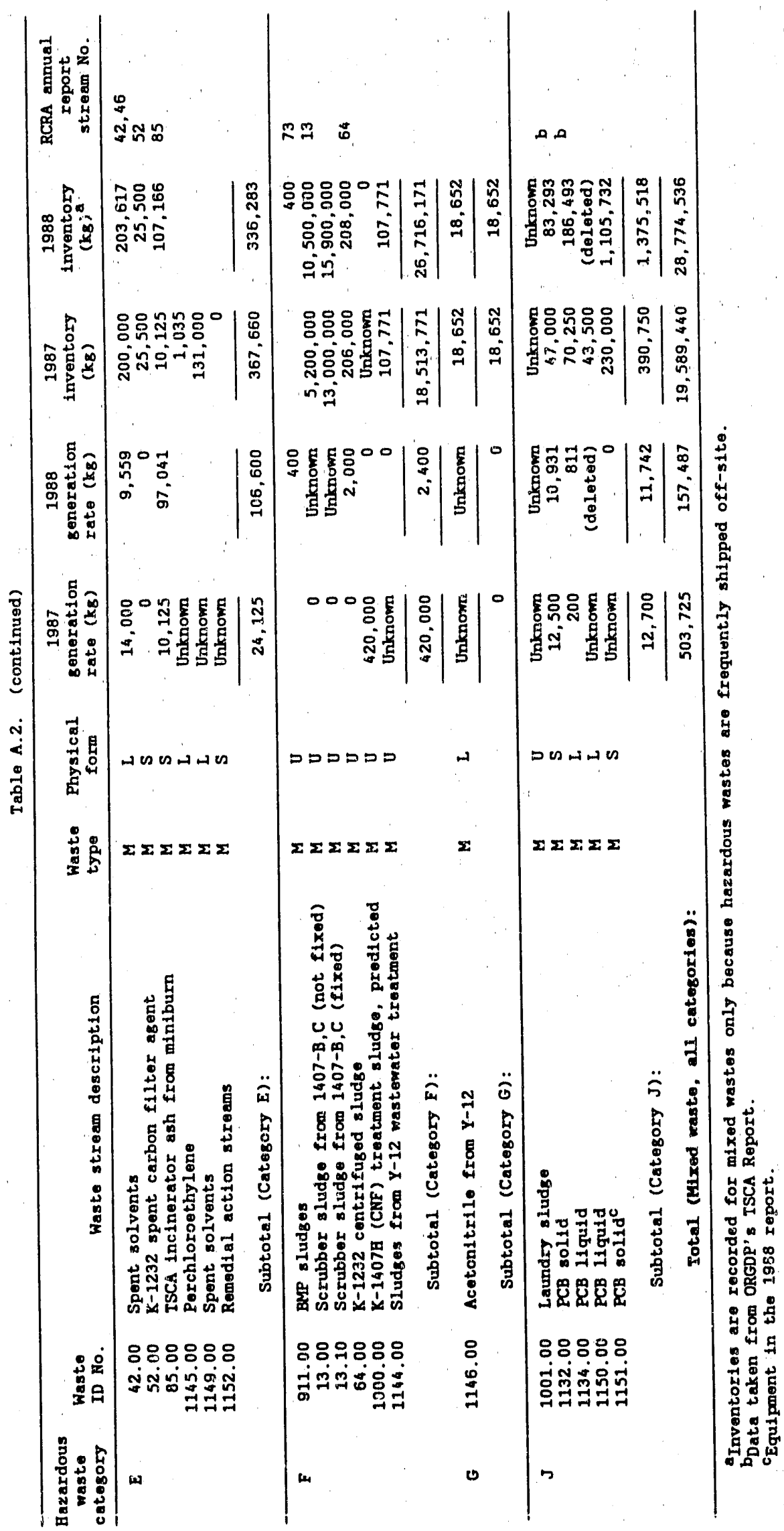




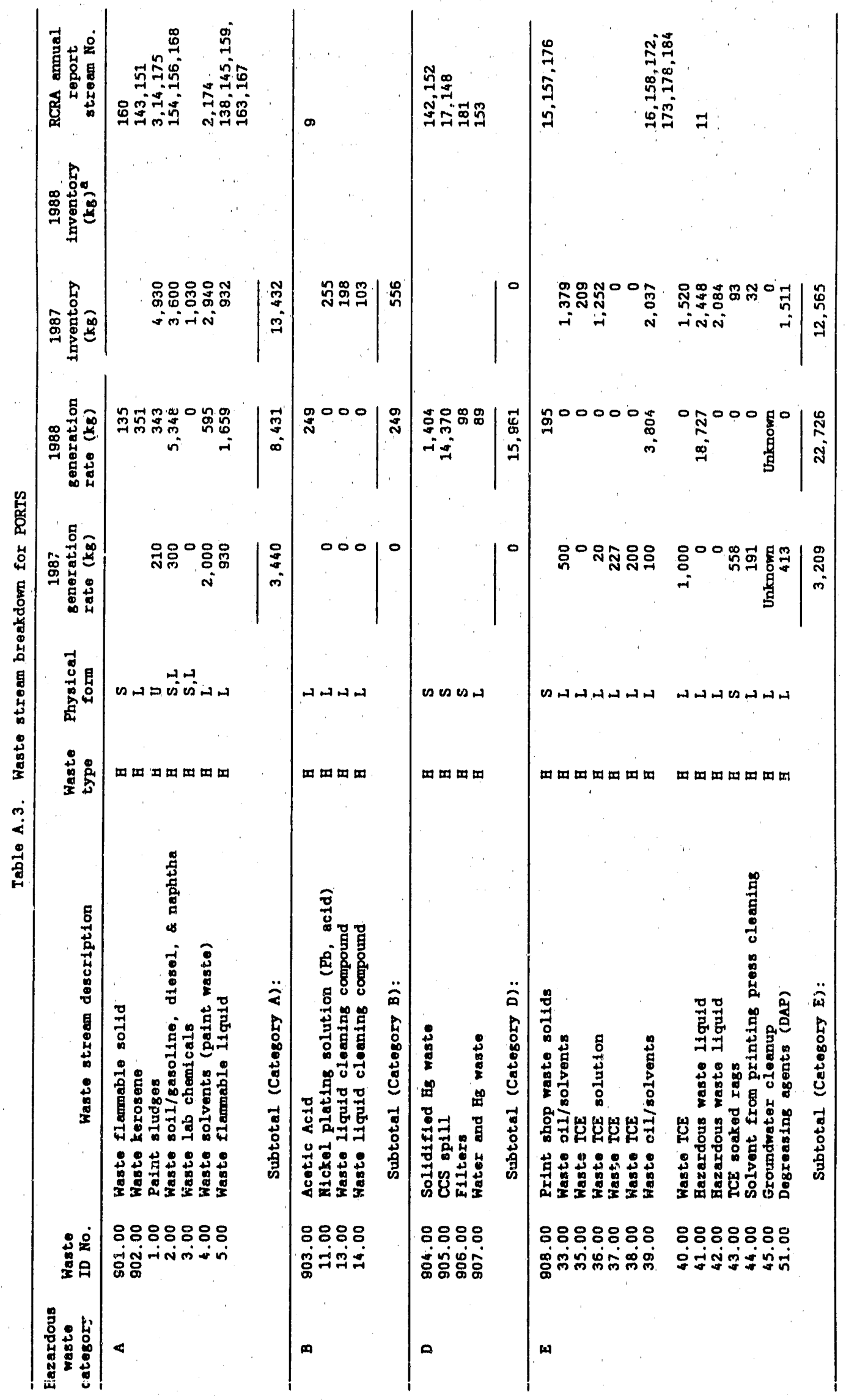




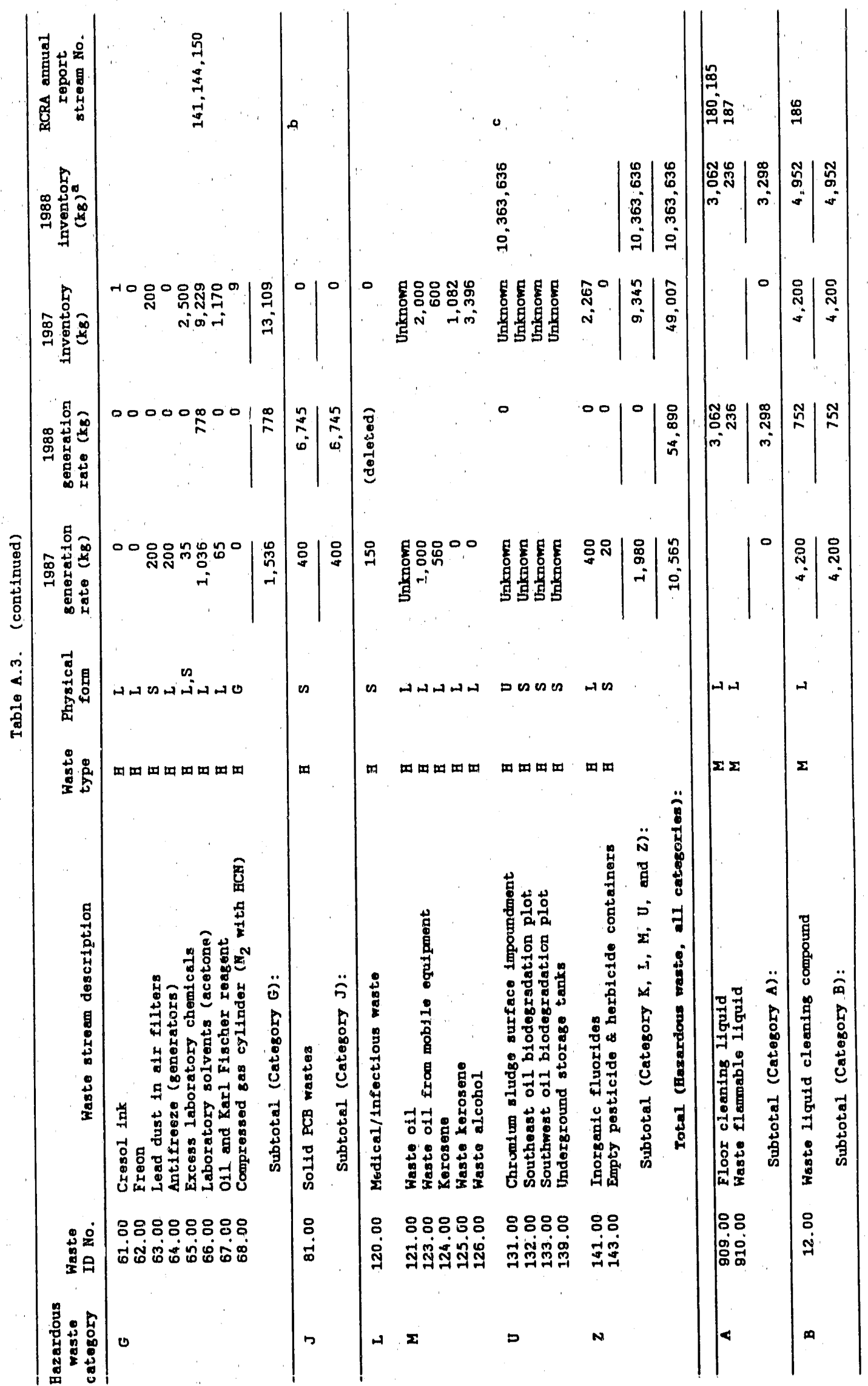




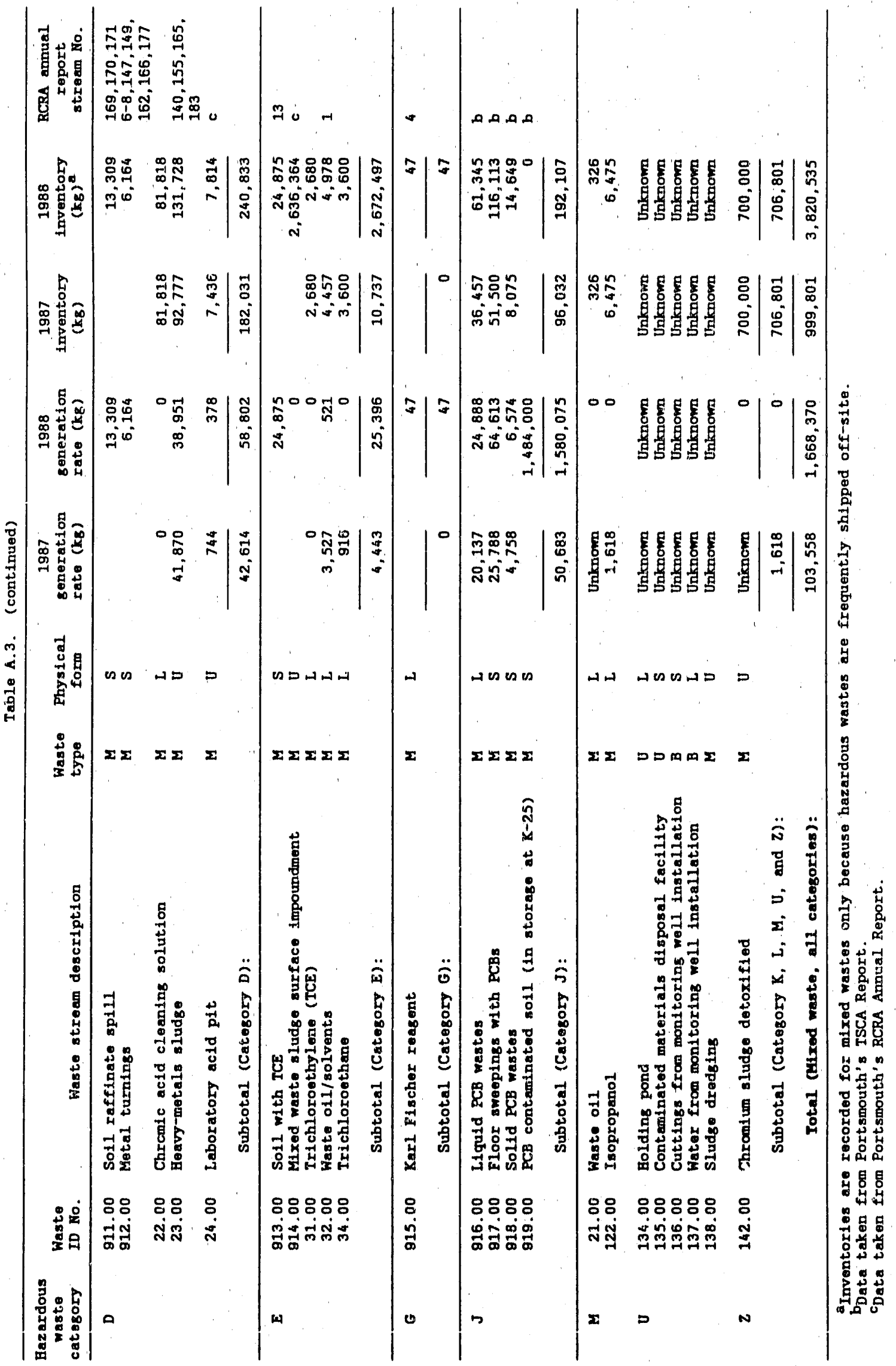




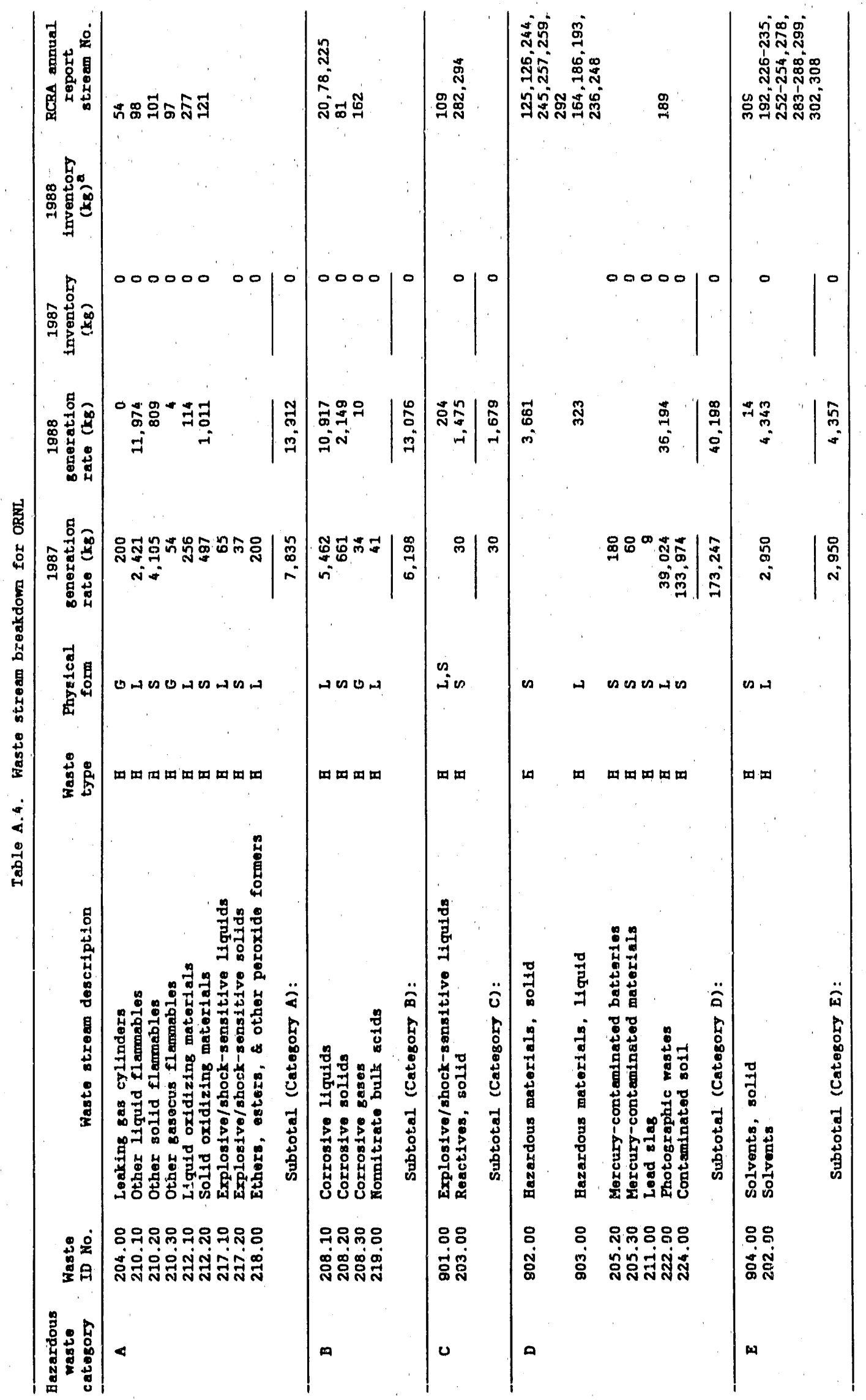




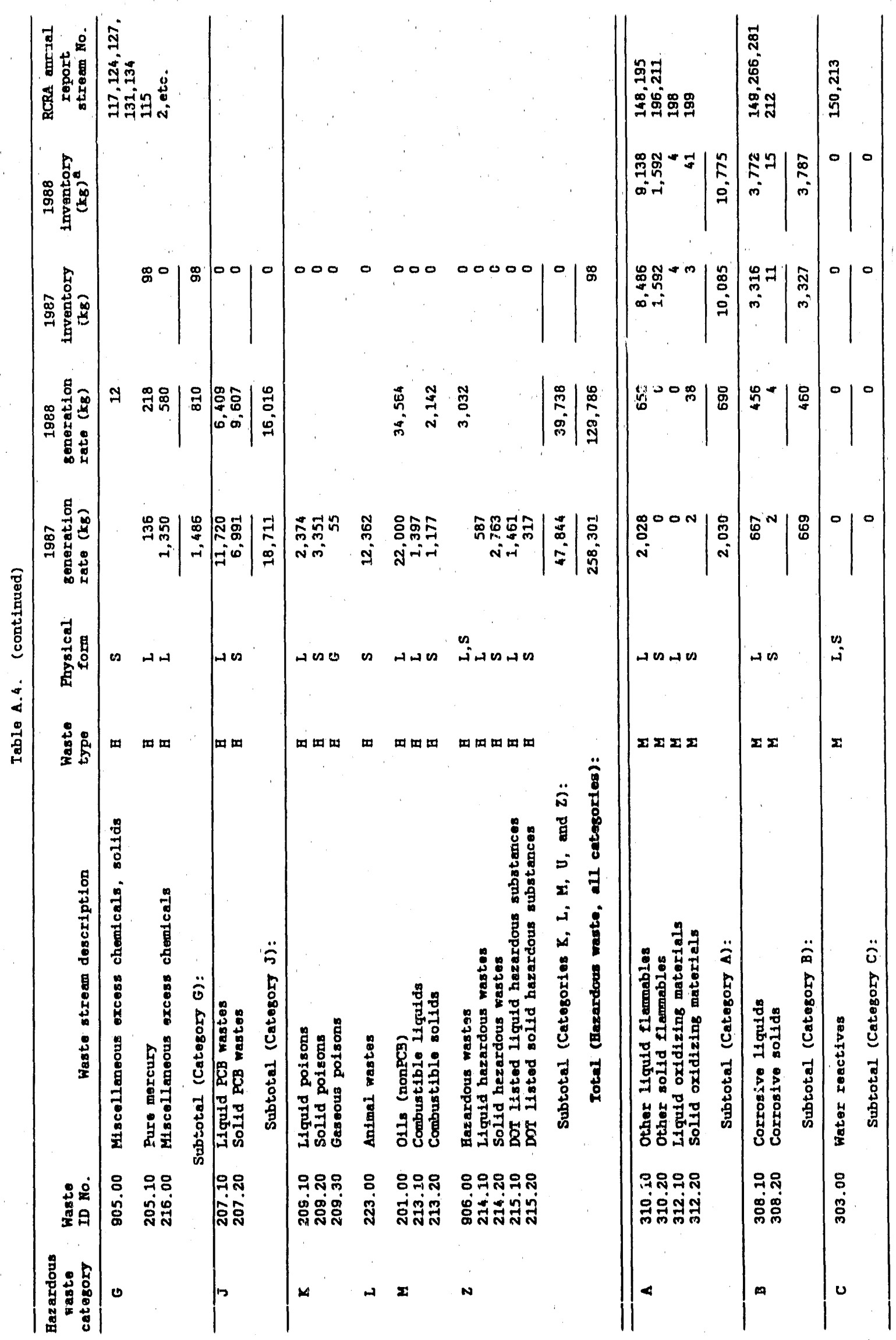




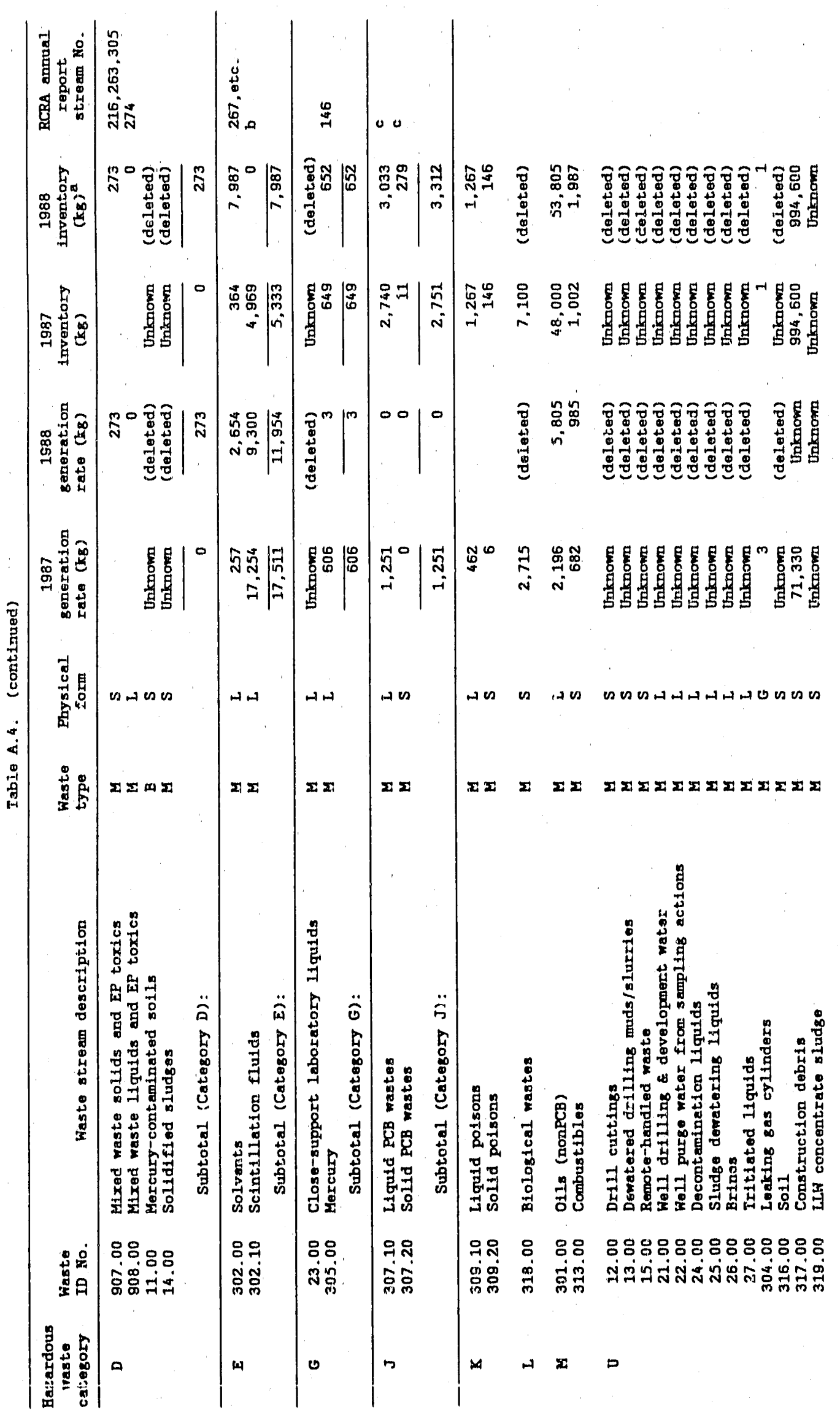




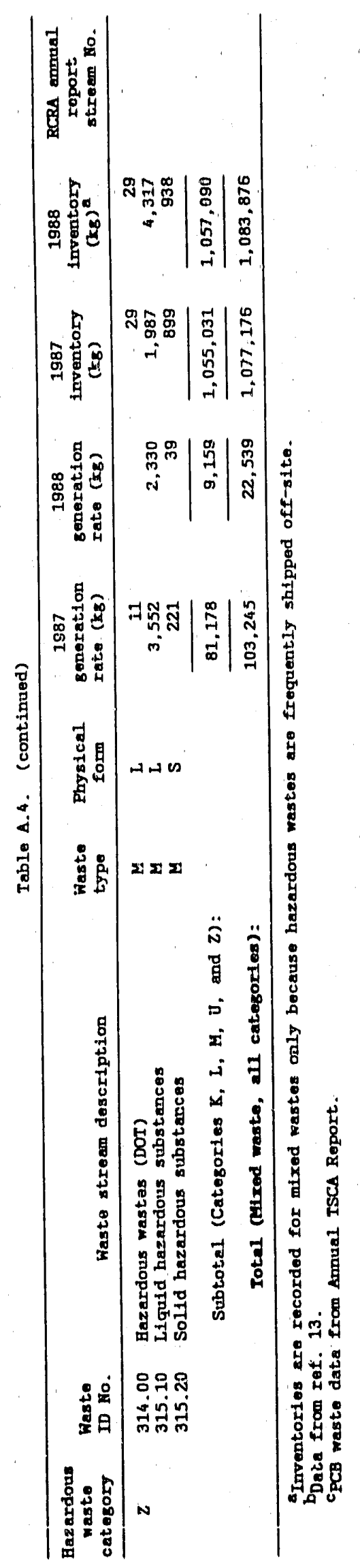




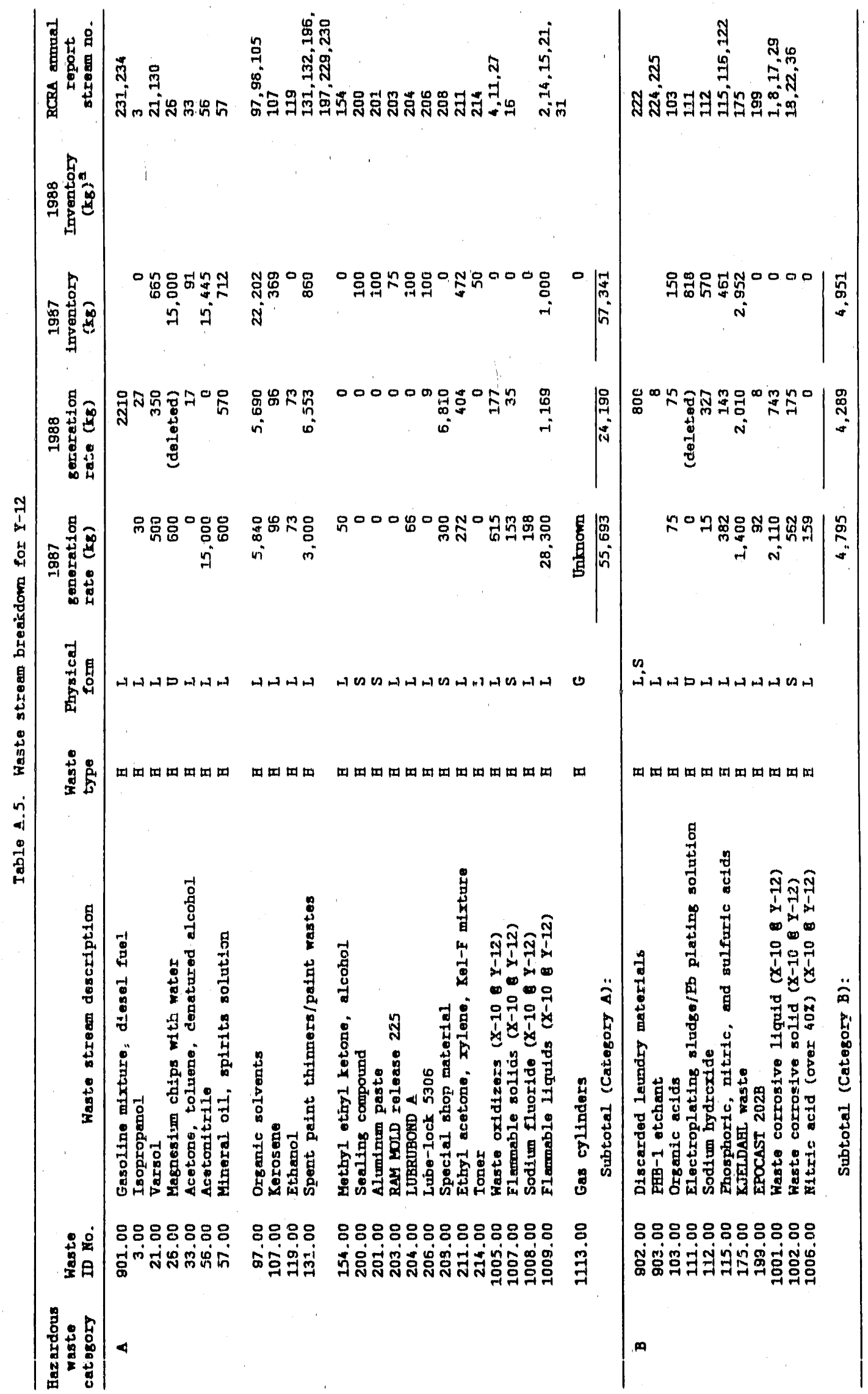




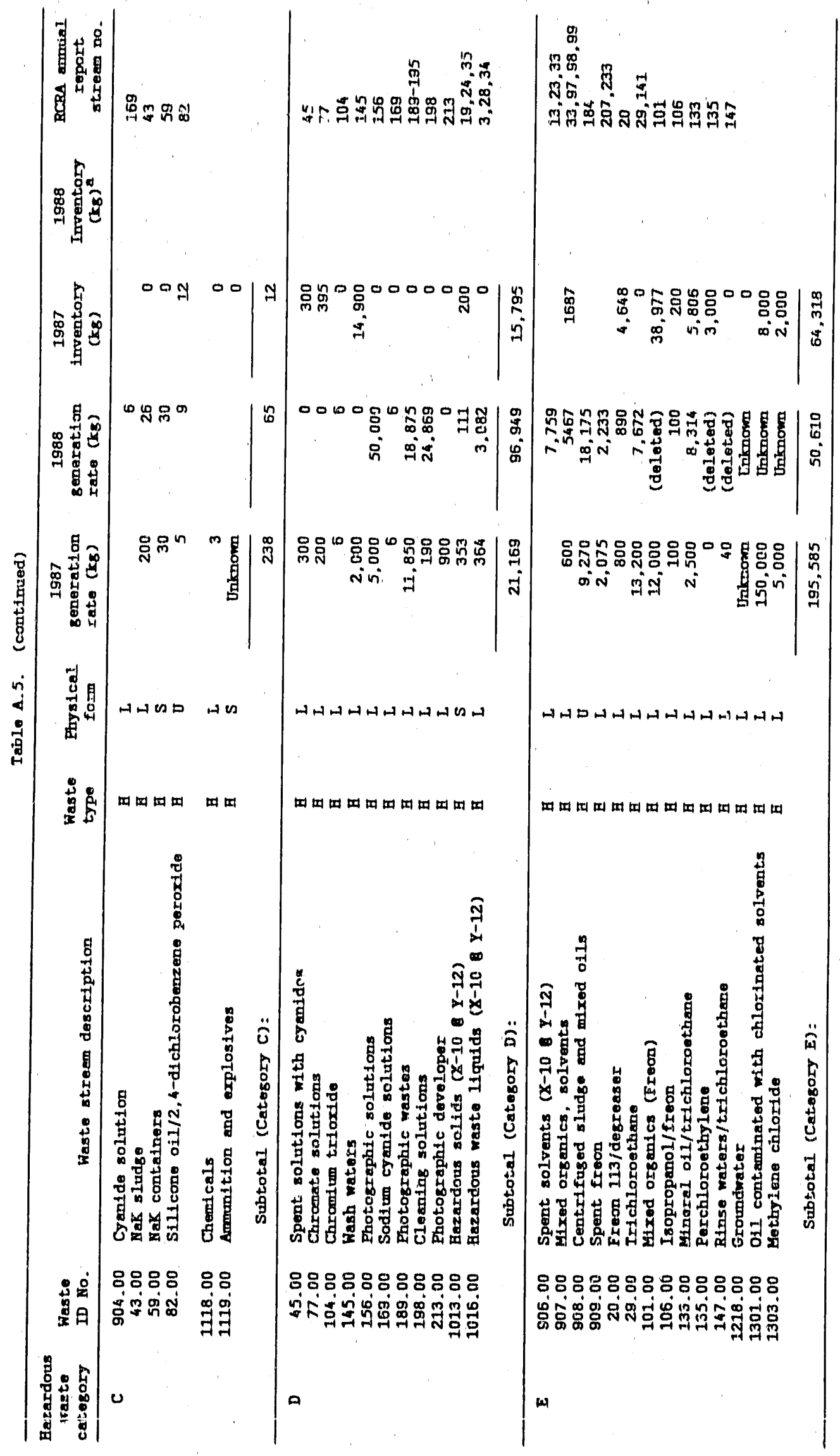




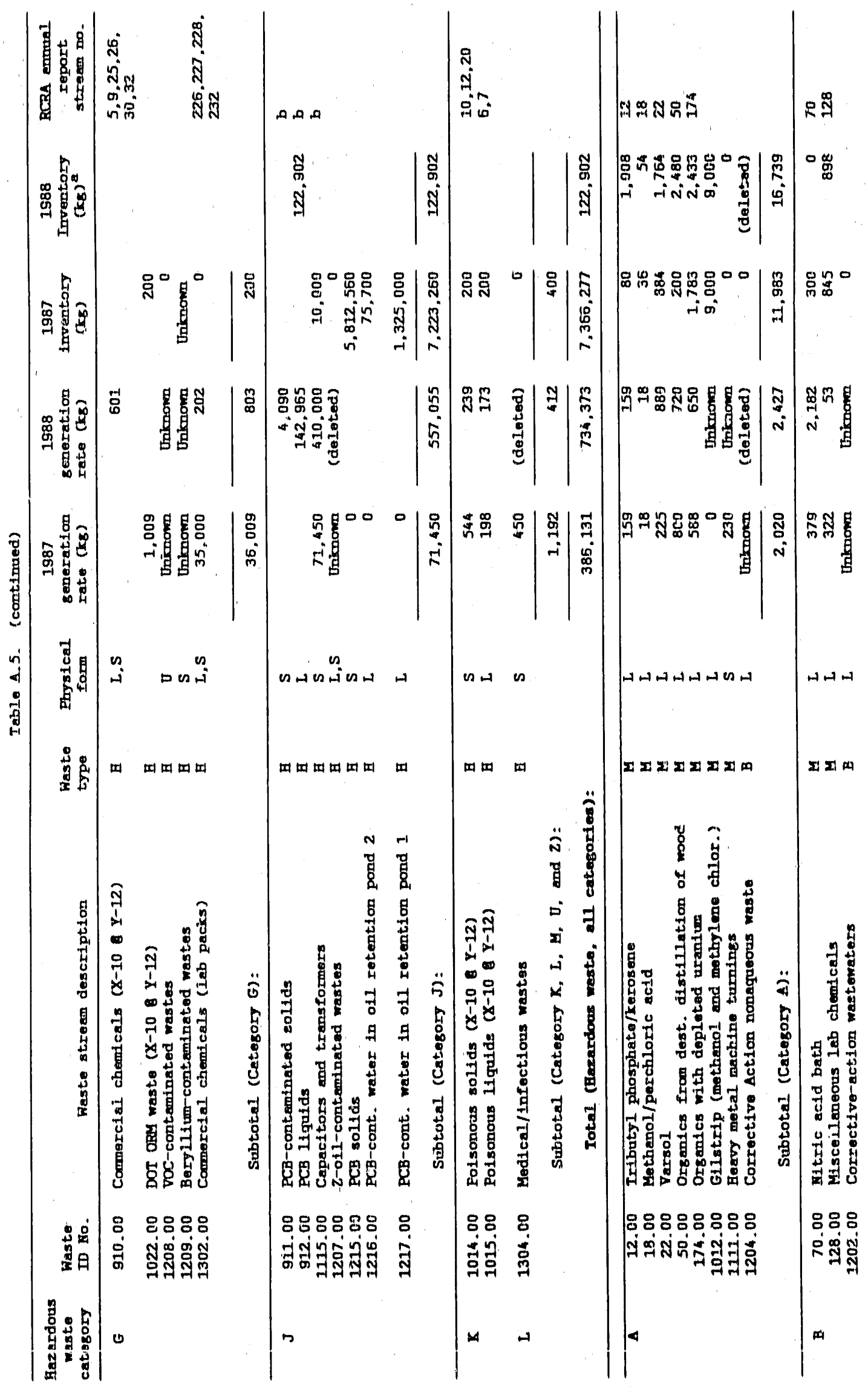




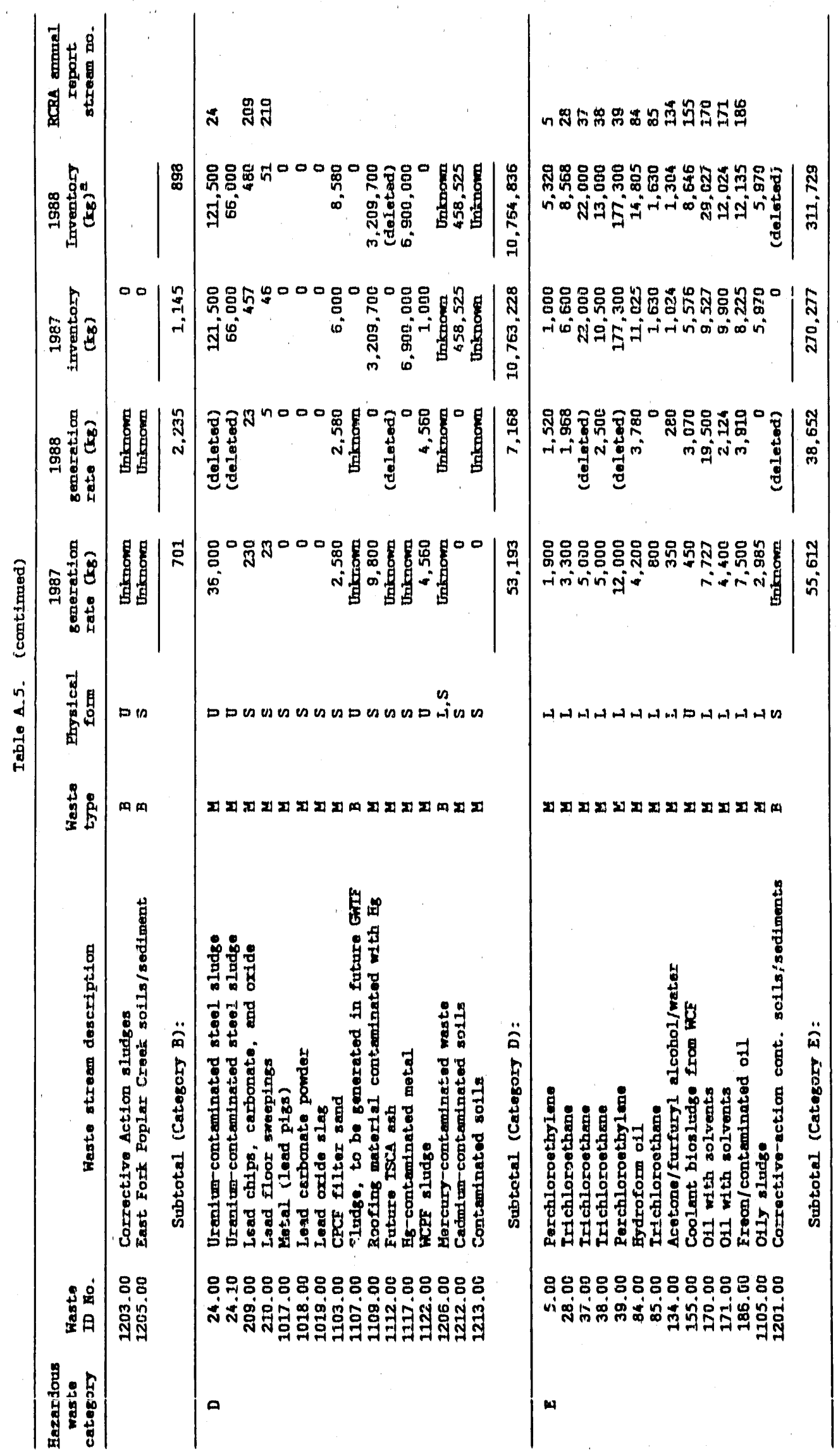




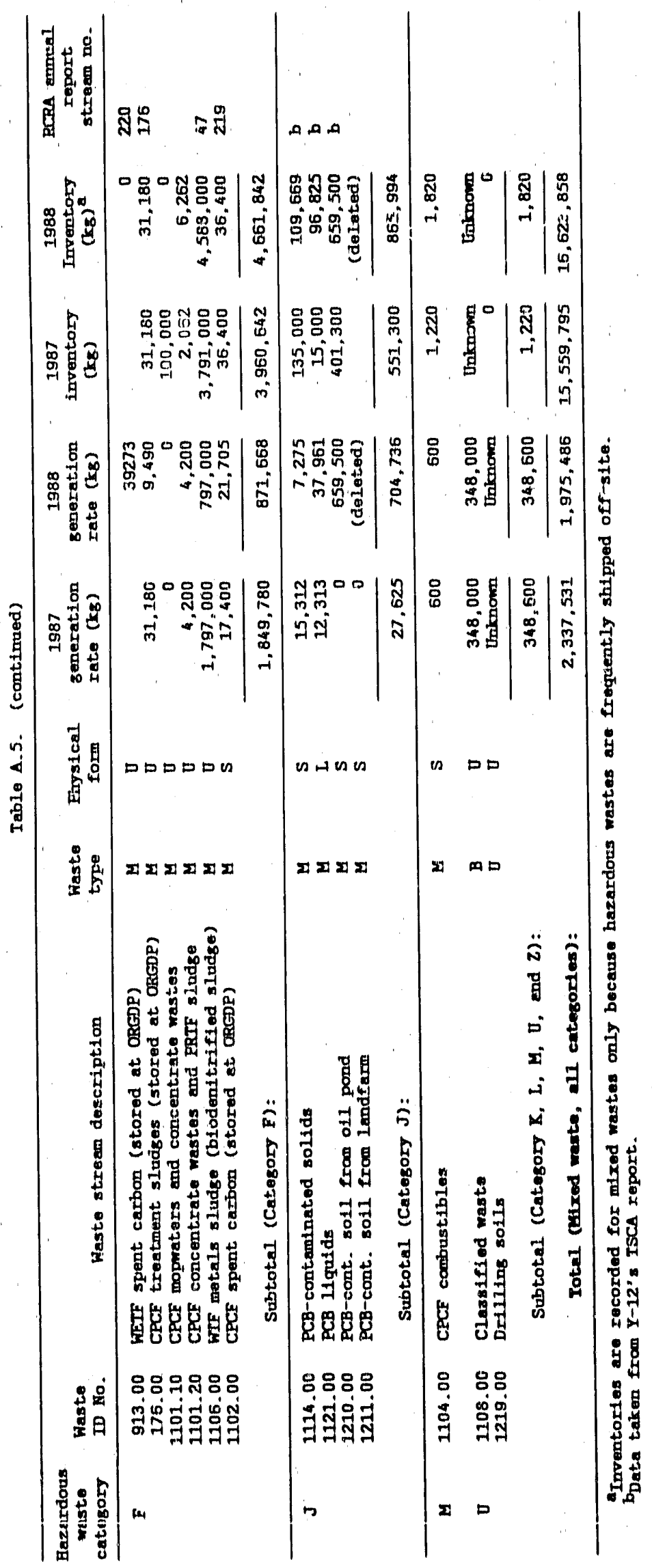


APPENDIX B

Total Waste Generation and Inventorles at Energy Systems Installations, by Waste Category, for Calendar Years 1987 and 1988 


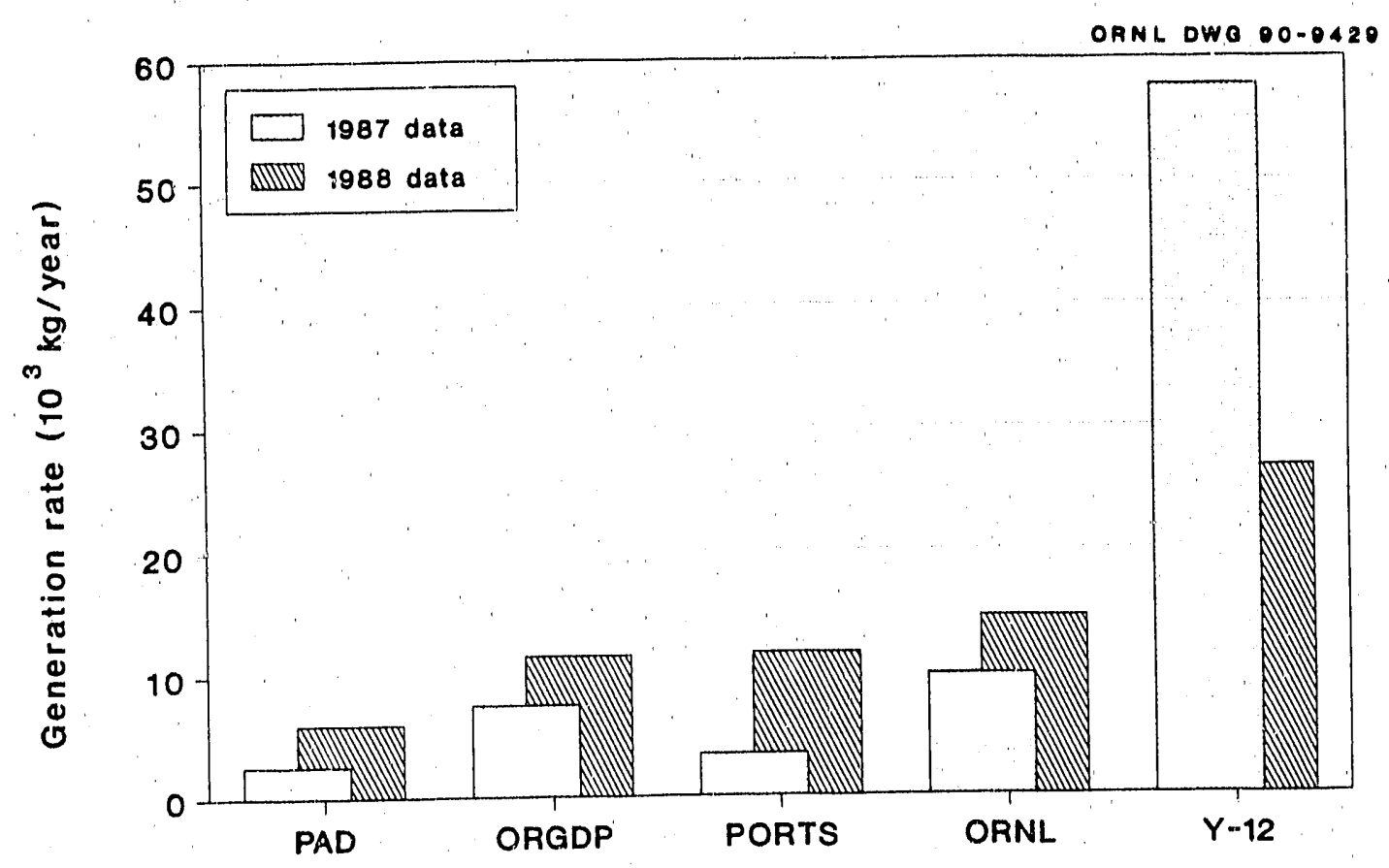

Fig. B.1. Category A (ignitable) total waste generation rates during 1987 and 1988 for all installations.

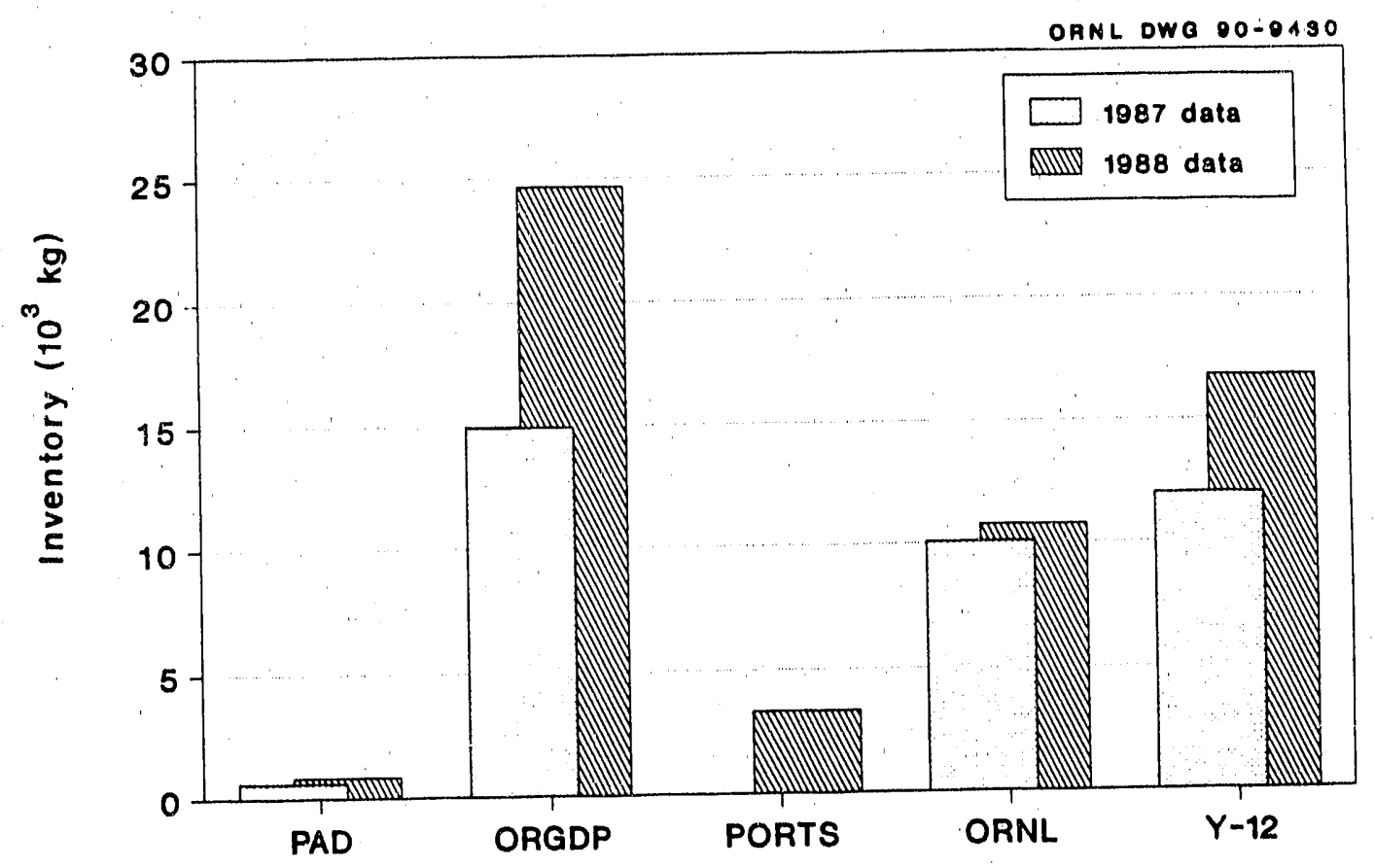

Fig. B.2. Category A (ignitable) mixed waste inventories during 1987 and 1988 for all installations. 


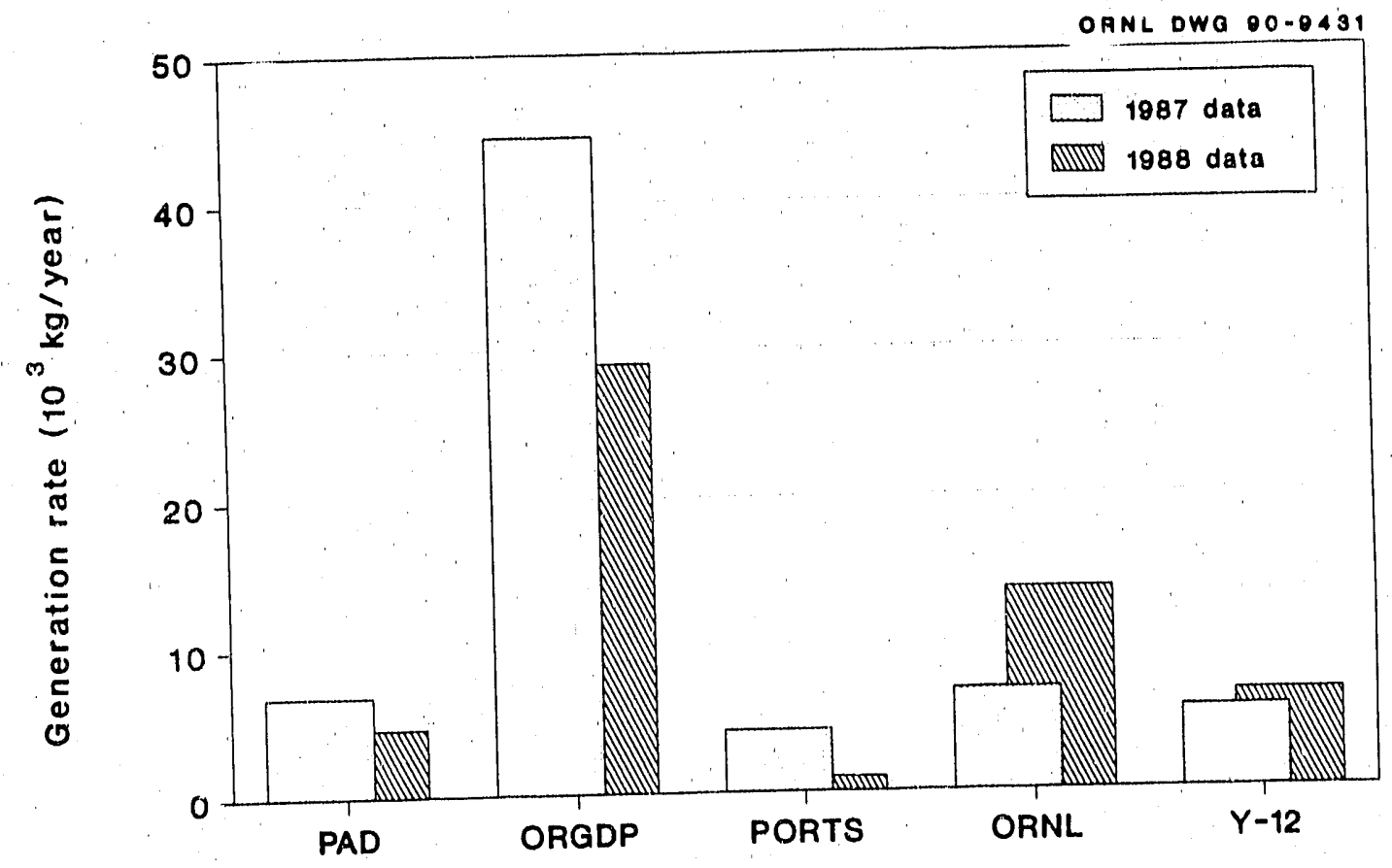

Fig. B.3. Category B (corrosive) total waste generation rates during 1987 and 1988 for all installations.

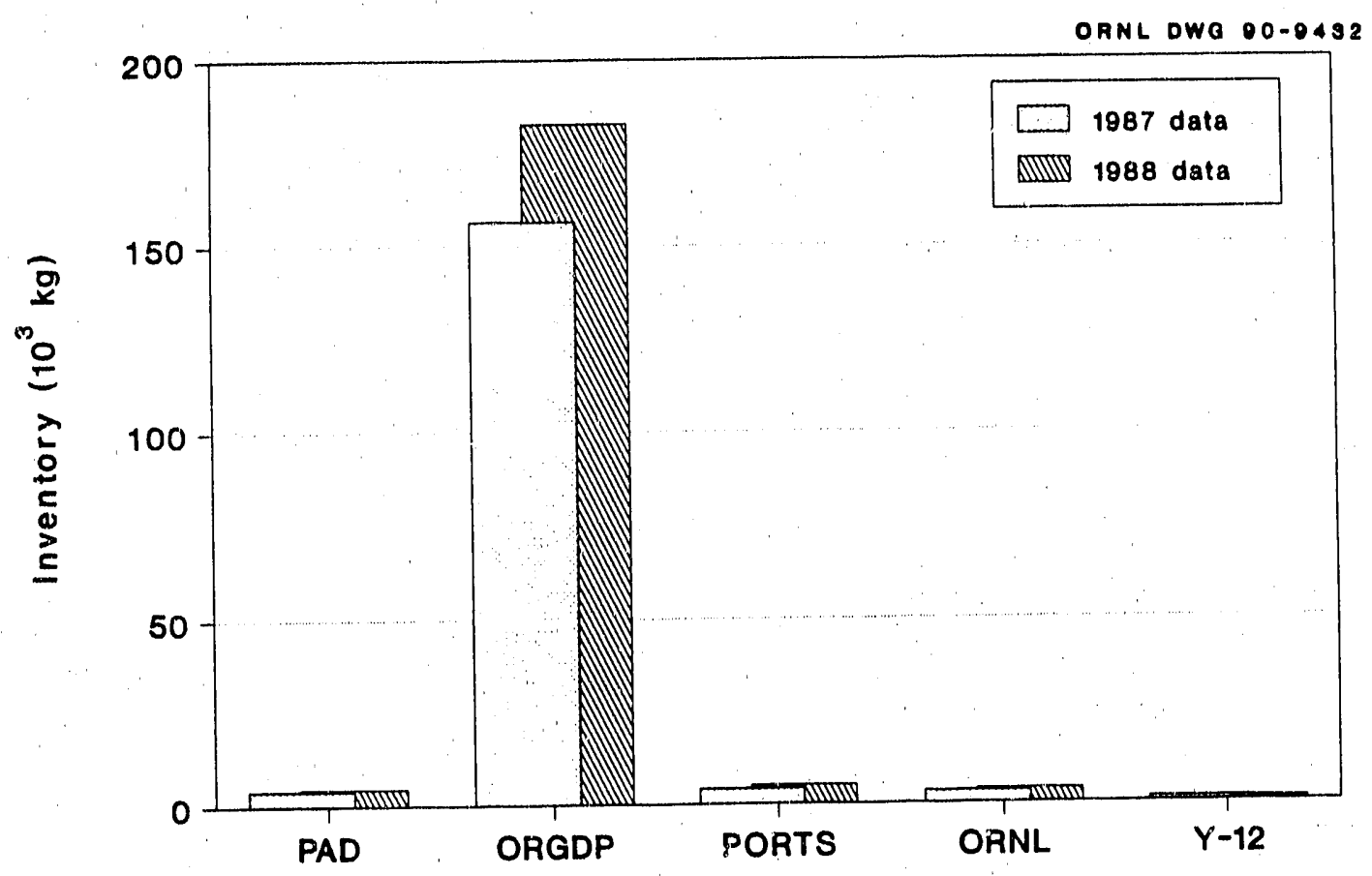

Fig. B.4. Category B (corrosive) mixed waste inventories during 1087 and 1988 for al1 installations. 


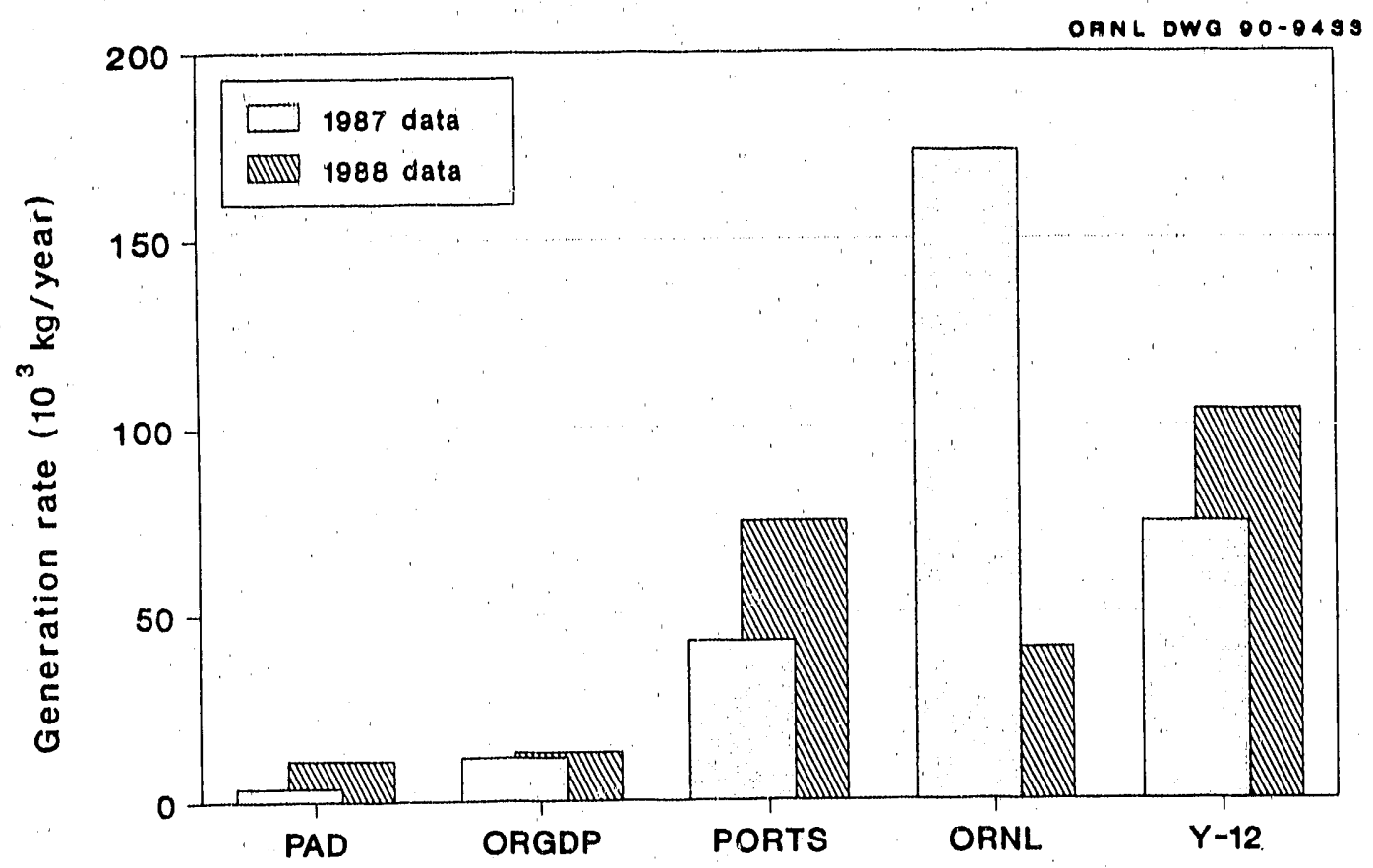

Fig. B.5. Category D (EP toxic) total waste generation rates during 1987 and 1988 for all installations.

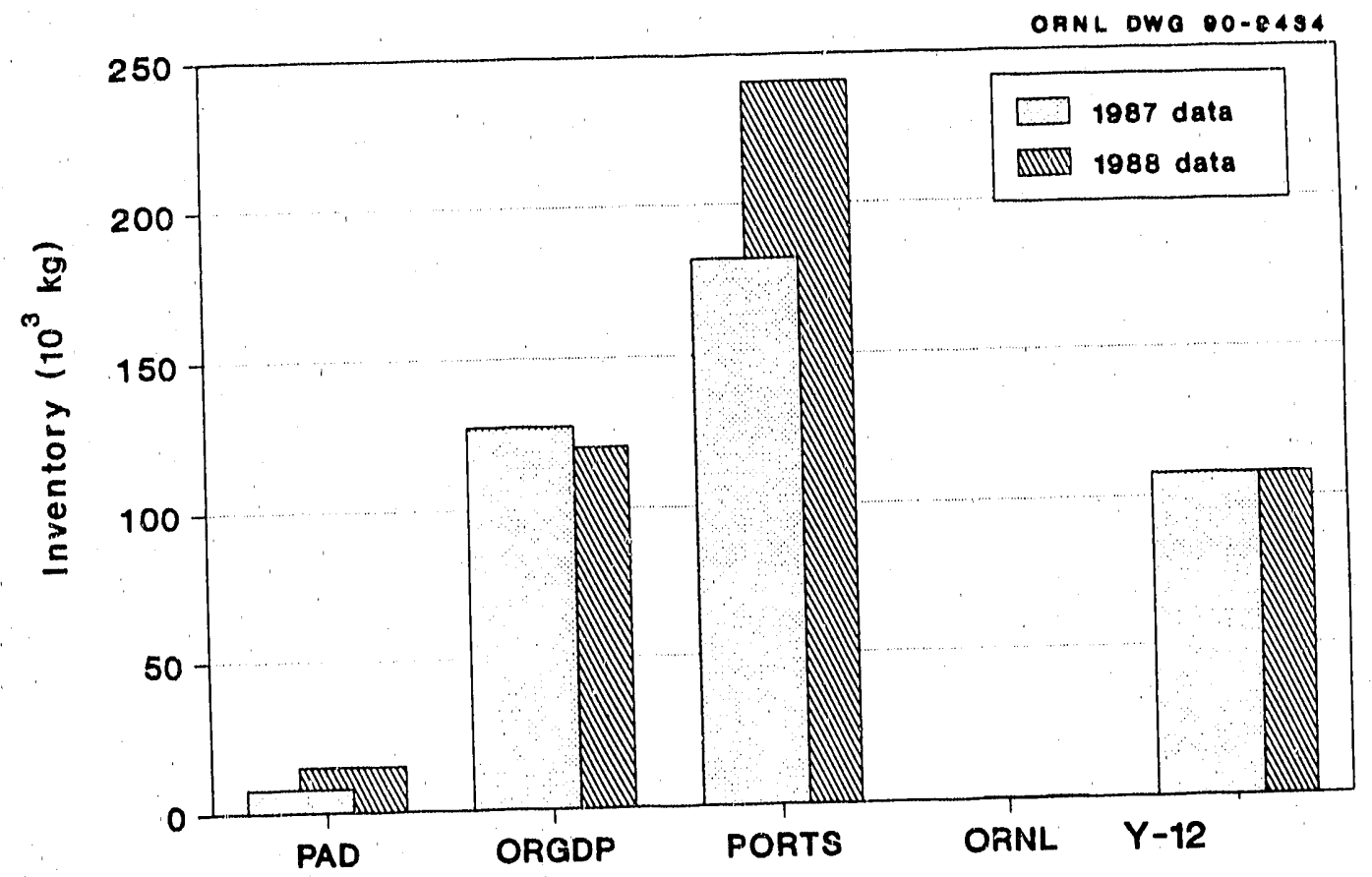

Fig. B.6. Category D (EP toxic) mixed waste inventories during 1987 and 1988 for all. installations. 


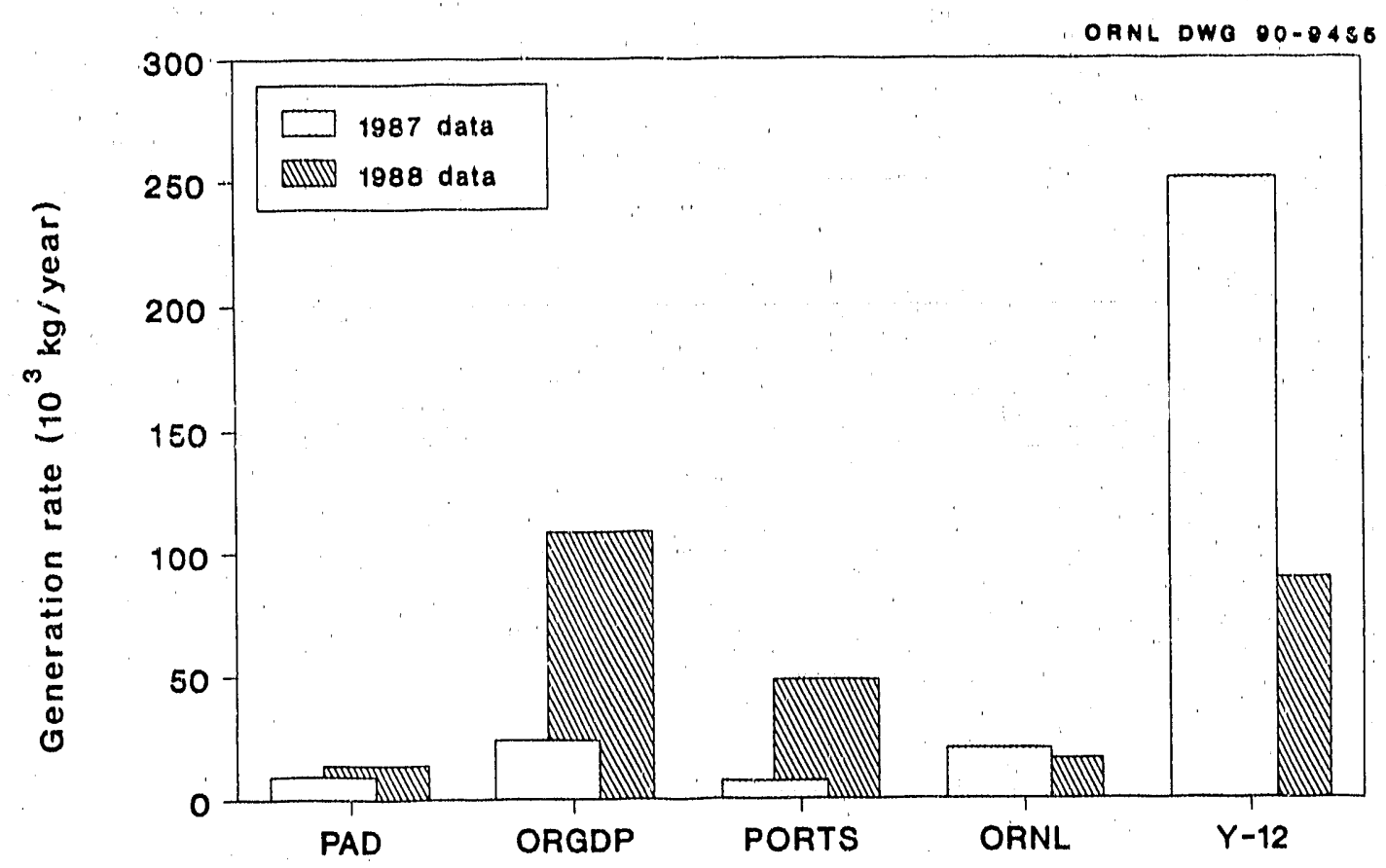

Fig. B.7. Category E (spent solvents) total waste generation rates during 1987 and 1988 for all installations.

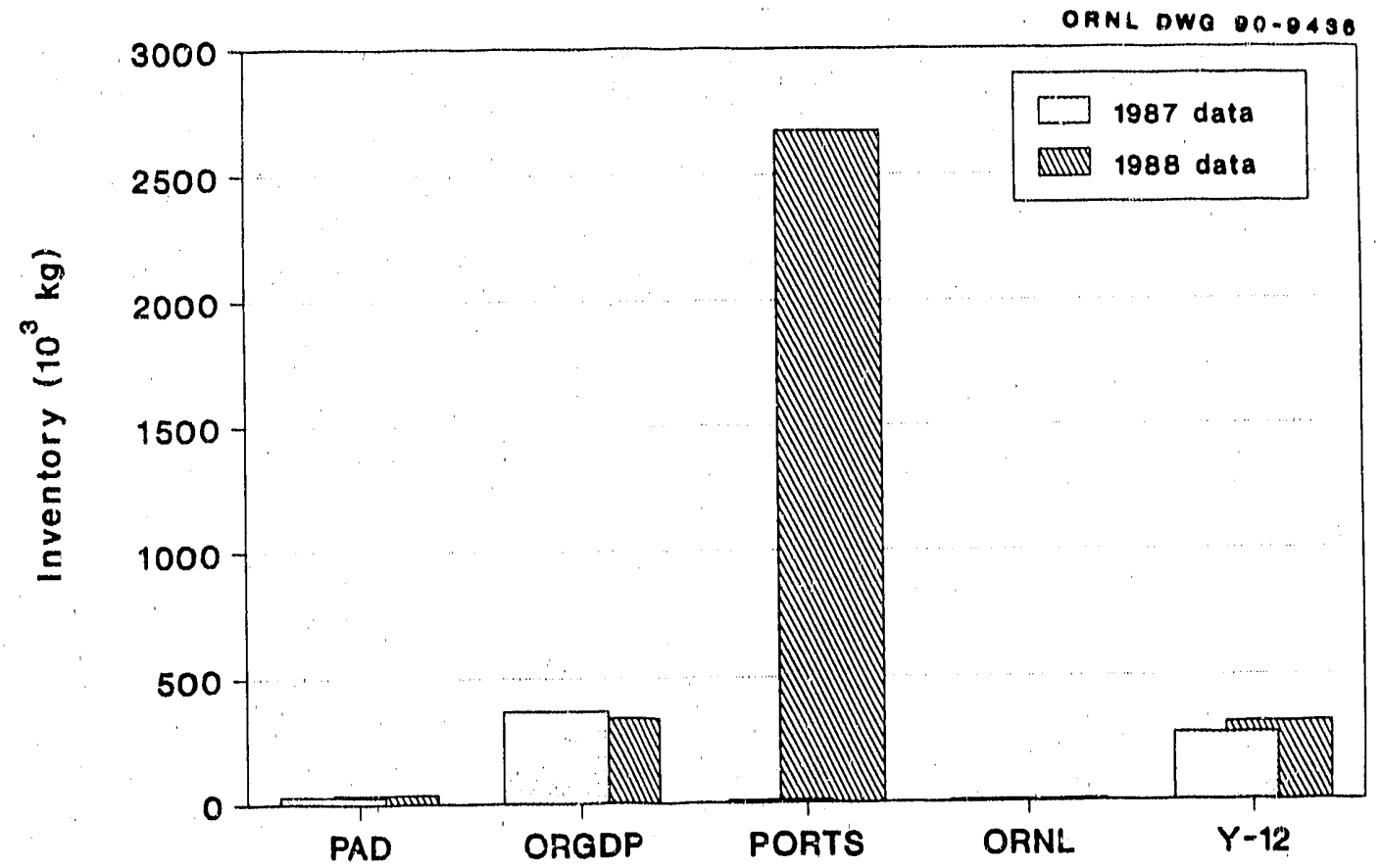

Fig. B.8. Category E (spent solvents) mixed waste inventories during 1987 and 1988 for all installations. 


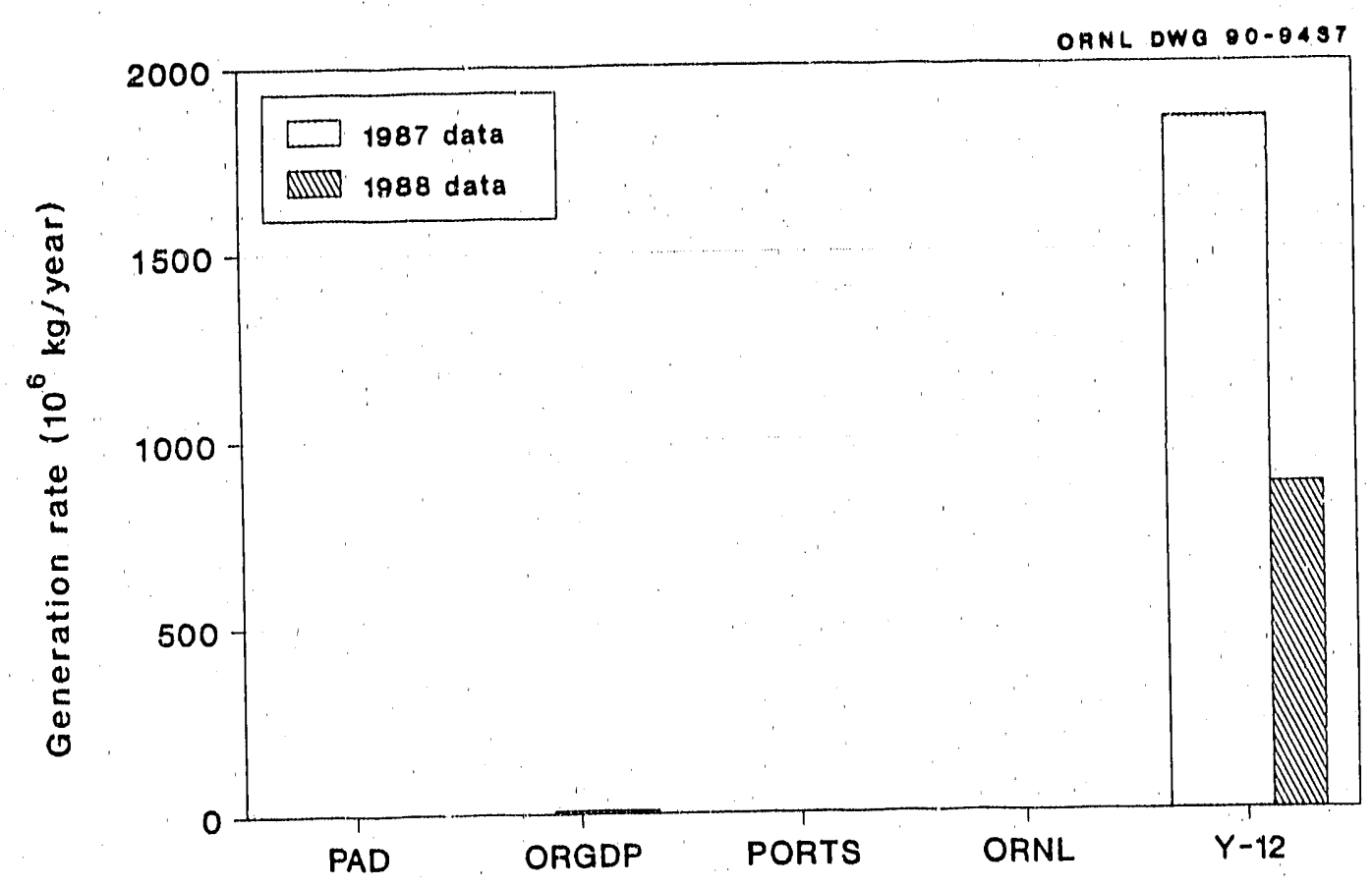

Fig. B.9. Category F (spent sludges) total waste generation rates during 1987 and 1988 for all installations.

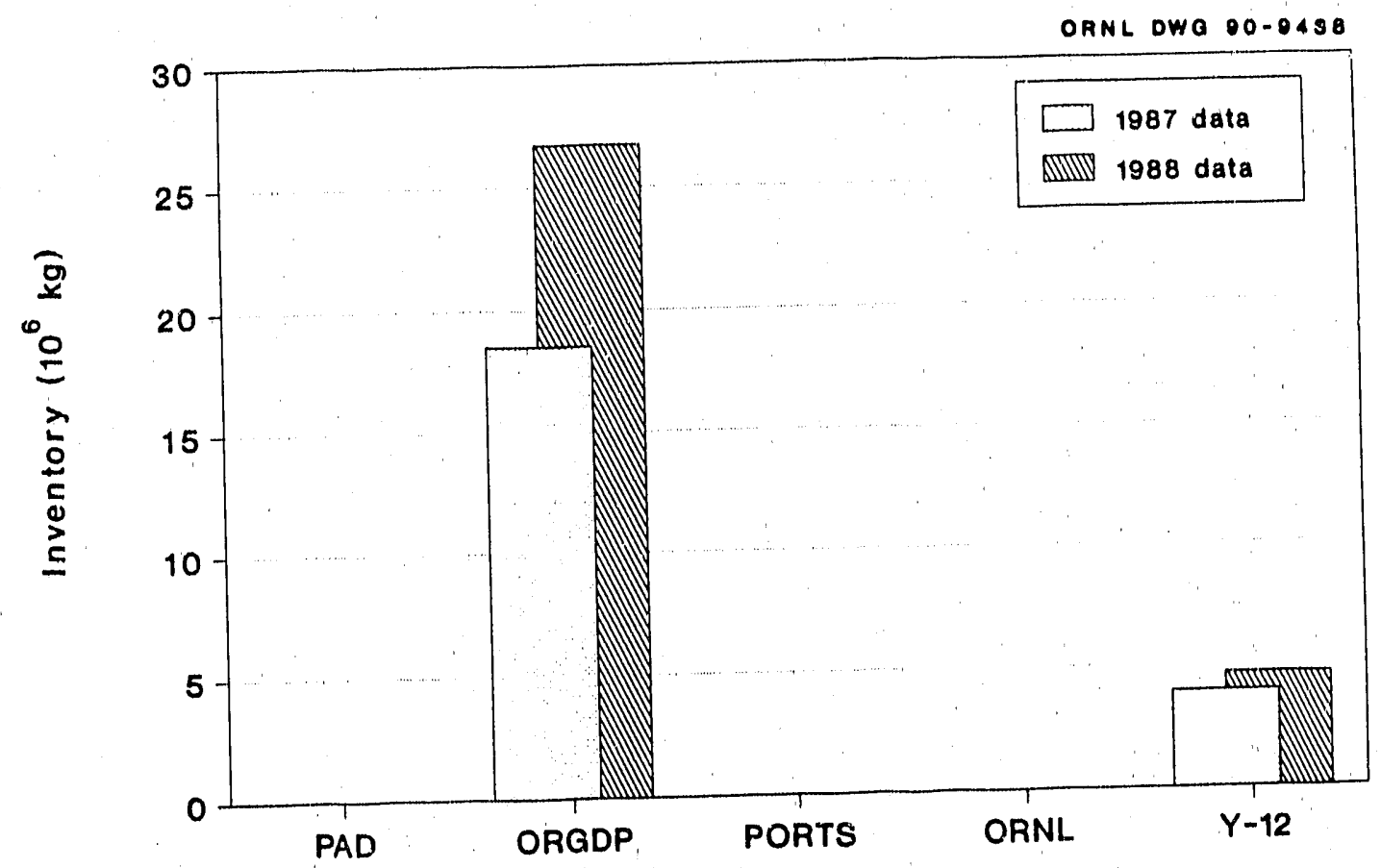

Fig. B.10. Category $F$ (spent sludges) mixed waste inventories during 1987 and 1988 for all installations. 


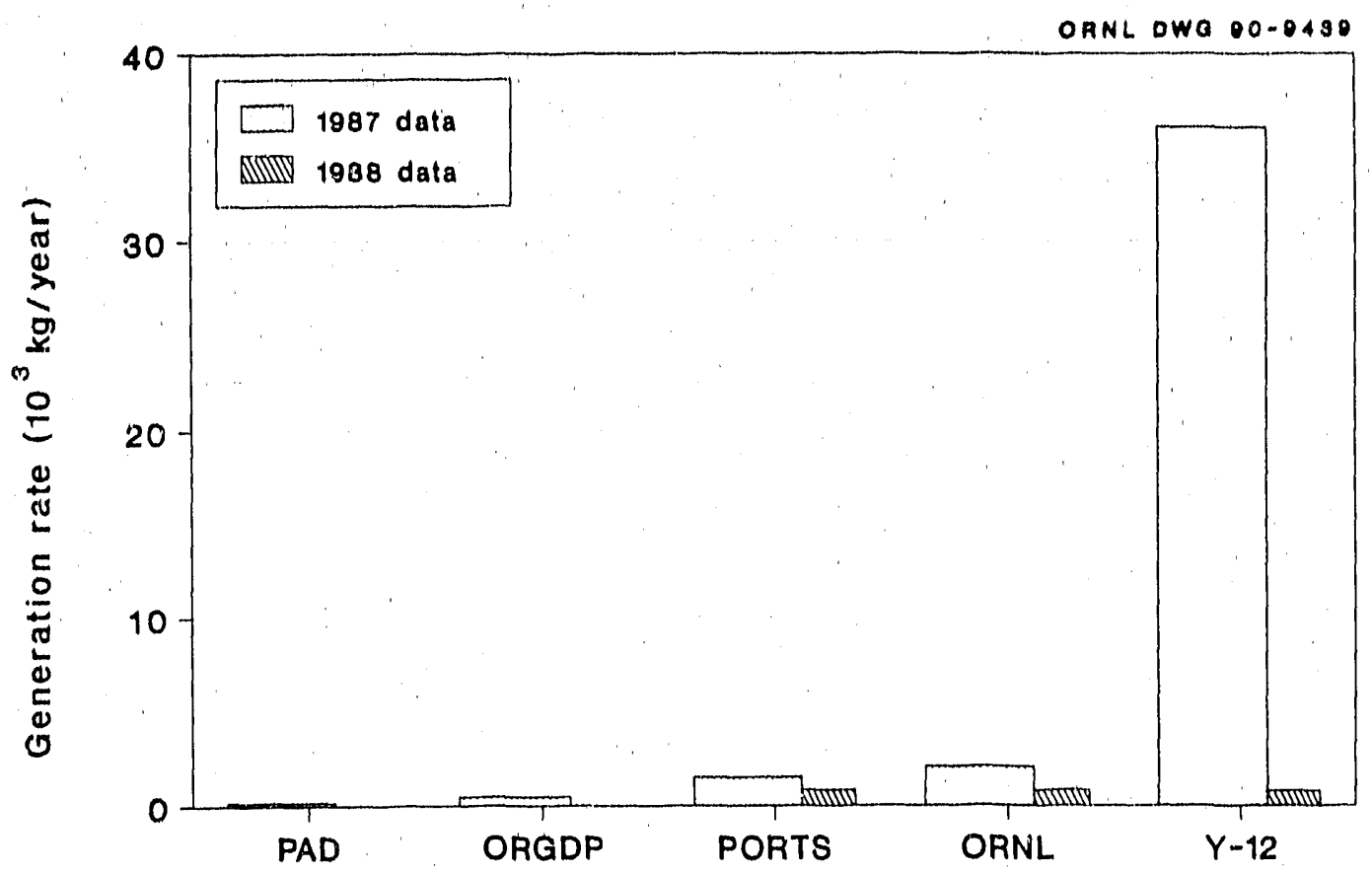

Fig. B.11. Category G (commercial chemical) total waste generation rates during 1987 and 1988 for all installations.

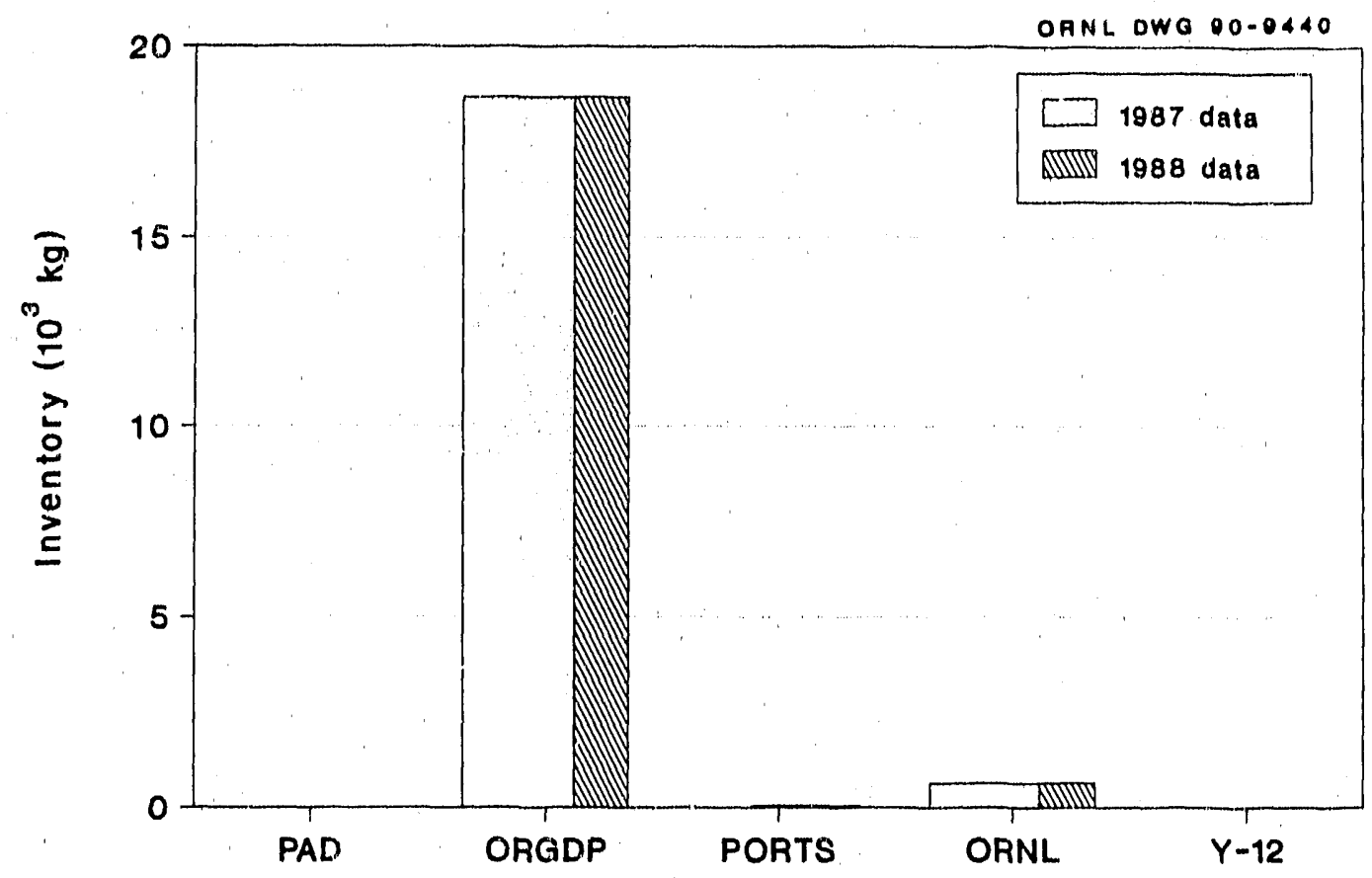

Fig. B.12. Category G (commercial chemica1) mixed waste inventorles during 1987 and 1988 for all installations. 


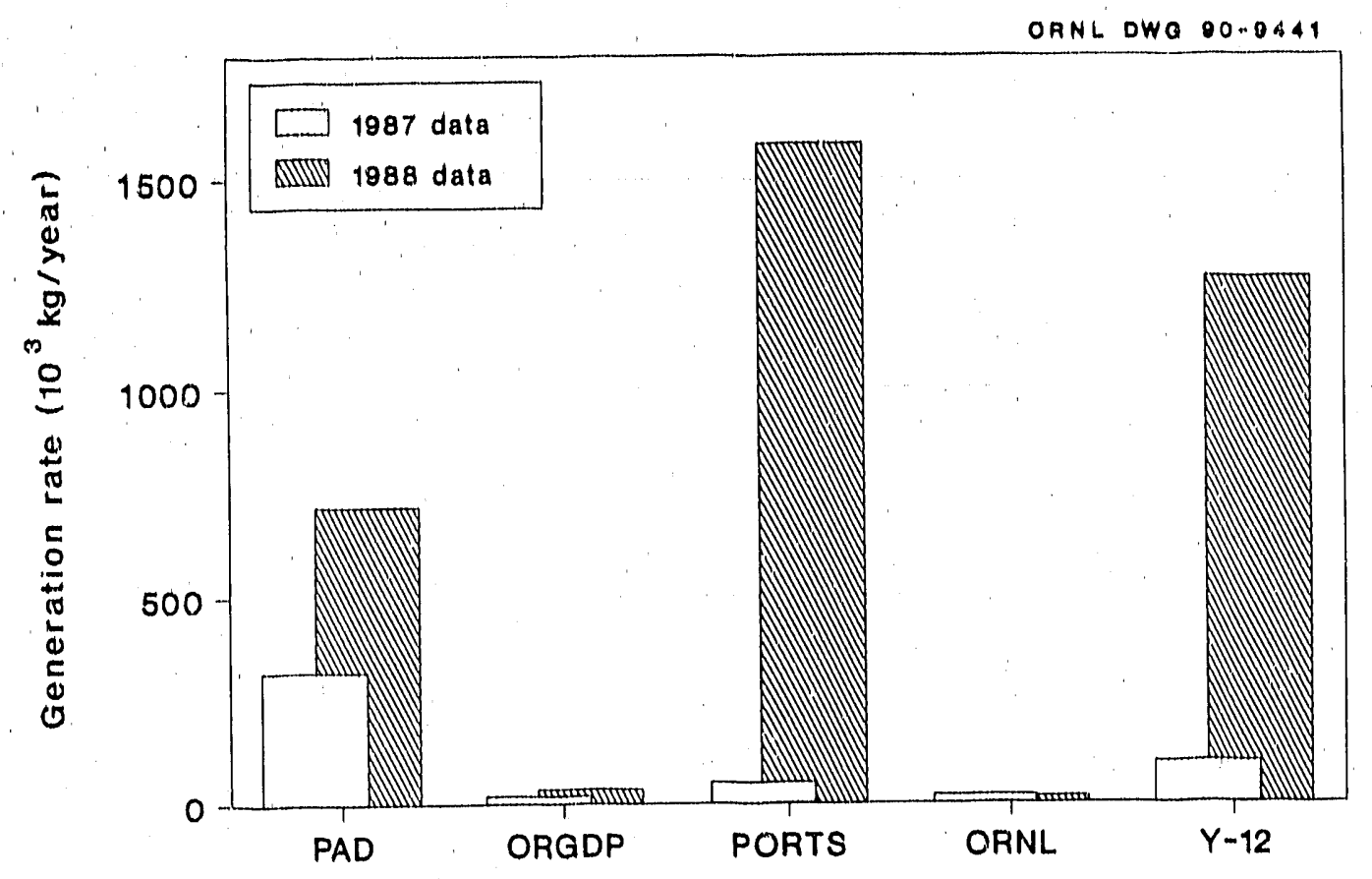

Fig. B.13. Category J (PCB-contaminated) total waste generation rates during 1987 and 1988 for all installations.

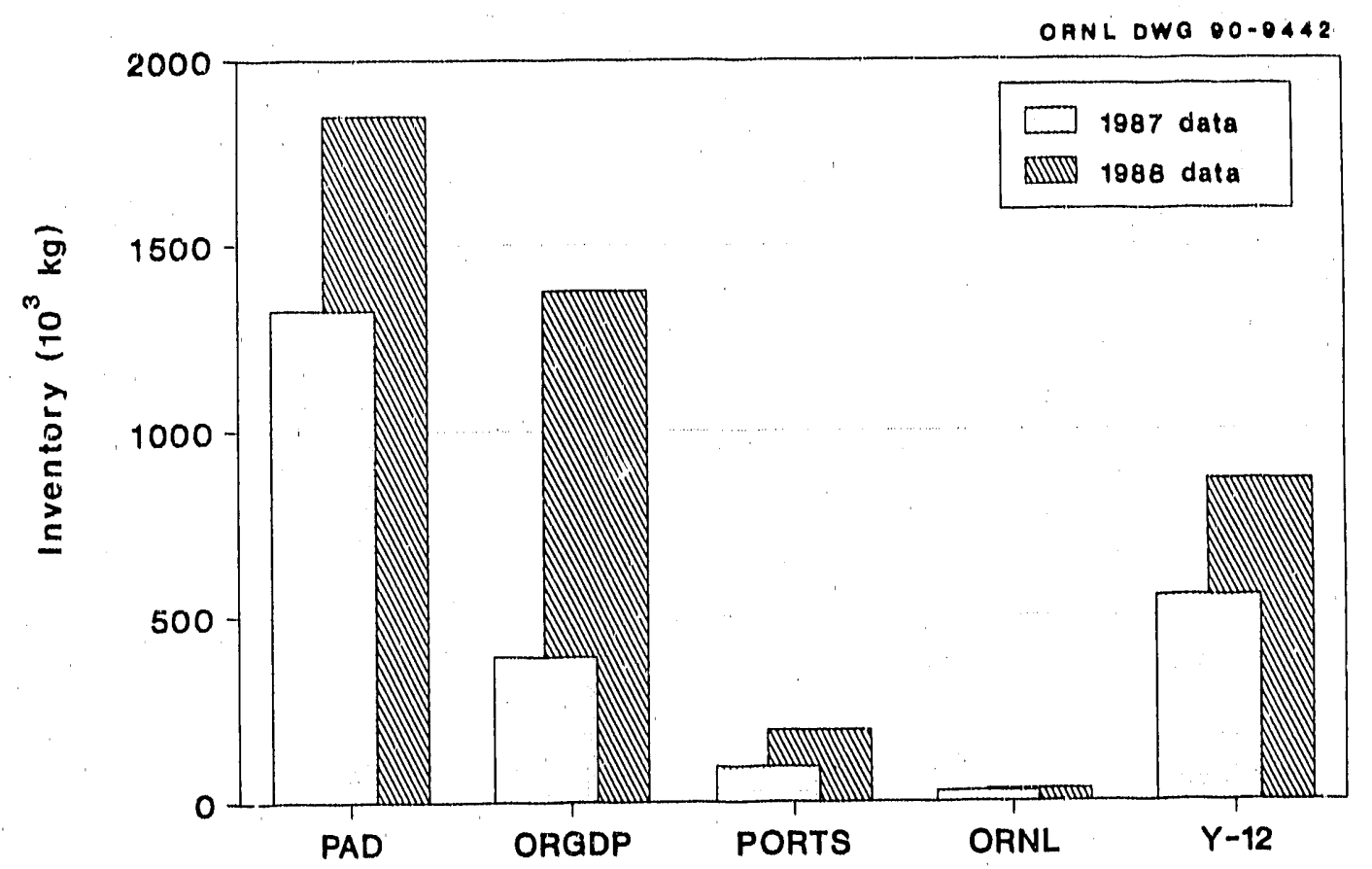

Fig, B.14. Category J (PCB-contaminated) mixed waste inventories during 1987 and 1988 for all installations. 


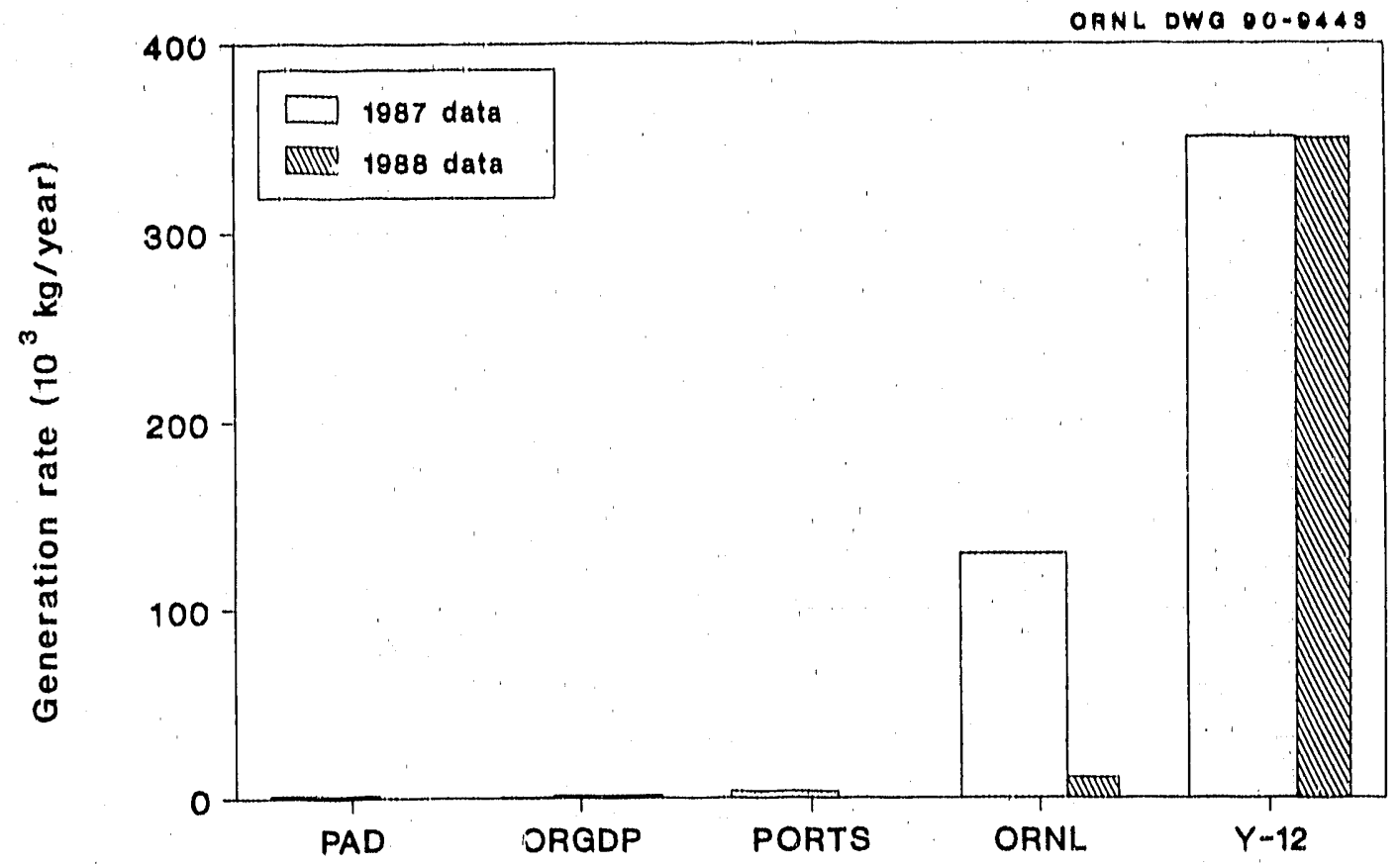

Fig. B.15. "Other" (reactive, combustible, etc.) total waste generation rates during 1987 and 1988 for all installations.

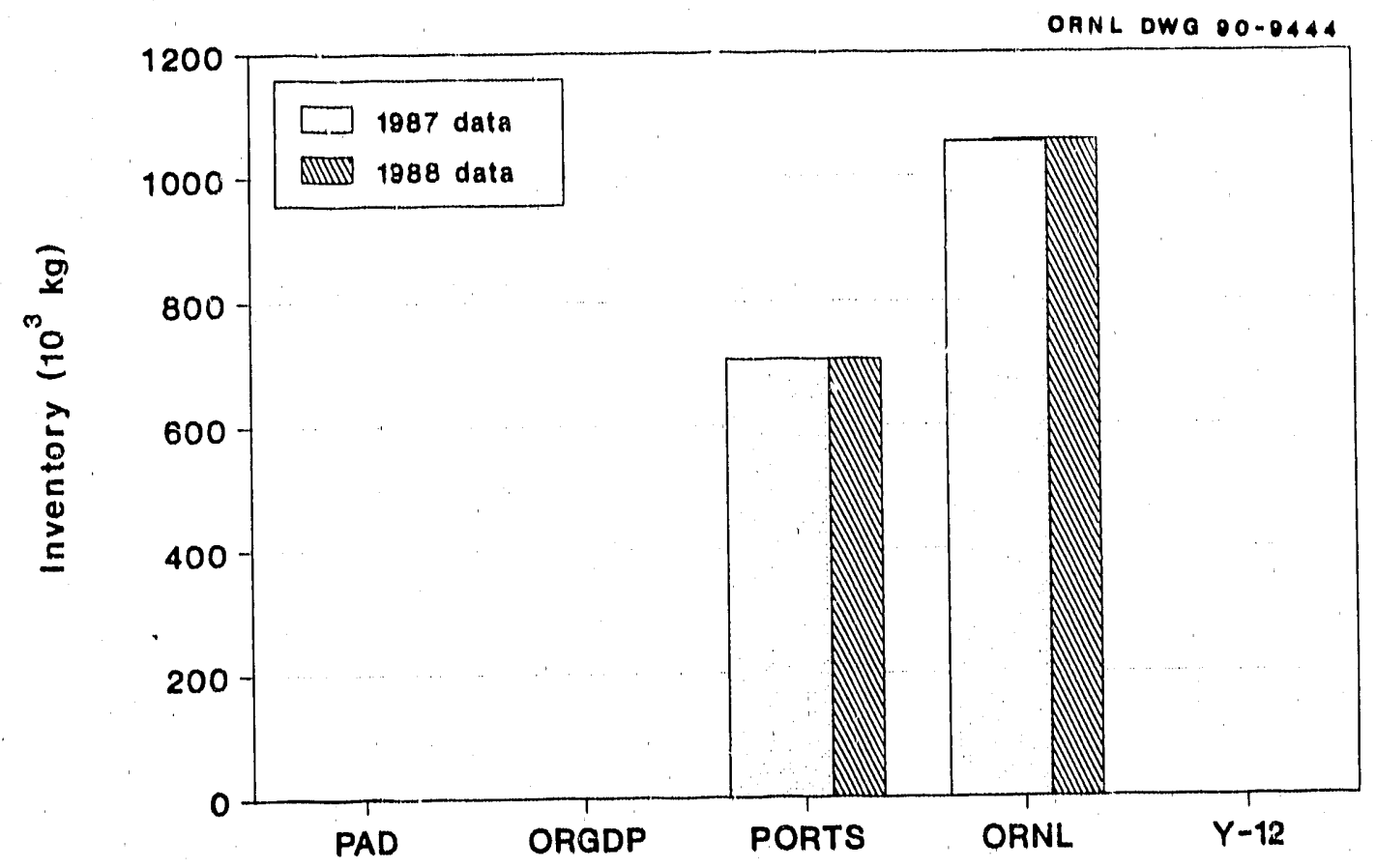

Fig. B.16. "Other" (reactive, combustible, etc.) mixed waste inventories during 1987 and 1988 for all installations. 

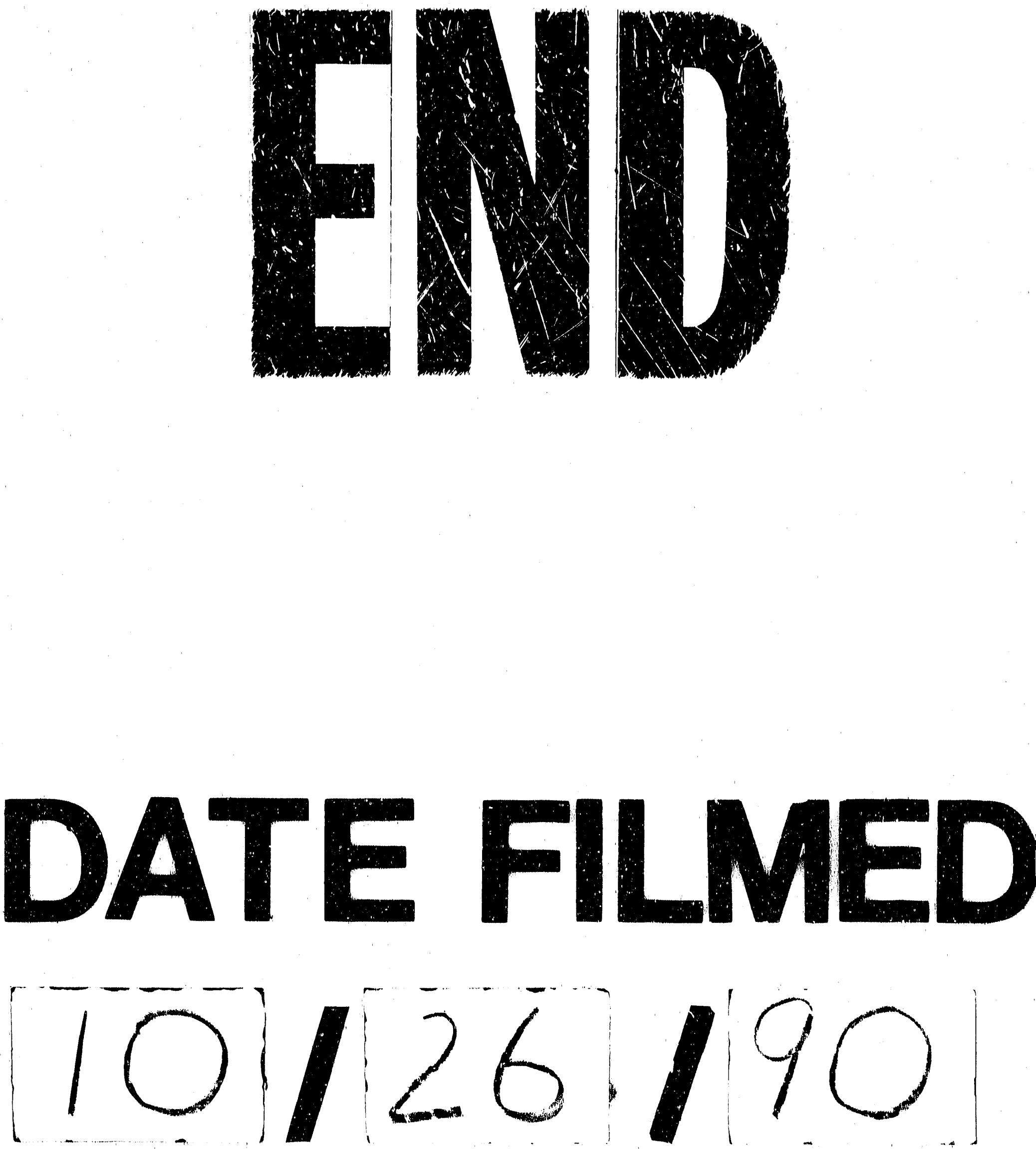
